\title{
From the periphery to the brain: Lipocalin-2, a friend or foe?
}

\author{
Ana C. Ferreira $^{a, b}$, Sandro Dá Mesquita ${ }^{a, b}$, João C. Sousa ${ }^{a, b}$, Margarida Correia-Neves ${ }^{a, b}$, \\ Nuno Sousa $^{\mathrm{a}, \mathrm{b}}$, Joana A. Palha ${ }^{\mathrm{a}, \mathrm{b}}$, Fernanda Marques ${ }^{\mathrm{a}, \mathrm{b}, *}$
}

${ }^{a}$ Life and Health Sciences Research Institute (ICVS), School of Health Sciences, University of Minho, Braga, Portugal

b ICVS/3B's - PT Government Associate Laboratory, Braga/Guimarães, Portugal

\section{A R T I C L E I N F O}

\section{Article history:}

Received 16 December 2014

Received in revised form 23 June 2015

Accepted 28 June 2015

Available online 6 July 2015

\section{Keywords:}

Lipocalin-2

Astrocytes

Central nervous system

Multiple sclerosis

Alzheimer's disease

Iron

\begin{abstract}
A B S T R A C T
Lipocalin-2 (LCN2) is an acute-phase protein that, by binding to iron-loaded siderophores, acts as a potent bacteriostatic agent in the iron-depletion strategy of the immune system to control pathogens. The recent identification of a mammalian siderophore also suggests a physiological role for LCN2 in iron homeostasis, specifically in iron delivery to cells via a transferrin-independent mechanism. LCN2 participates, as well, in a variety of cellular processes, including cell proliferation, cell differentiation and apoptosis, and has been mostly found up-regulated in various tissues and under inflammatory states, being its expression regulated by several inducers.

In the central nervous system less is known about the processes involving LCN2, namely by which cells it is produced/secreted, and its impact on cell proliferation and death, or in neuronal plasticity and behaviour. Importantly, LCN2 recently emerged as a potential clinical biomarker in multiple sclerosis and in ageing-related cognitive decline. Still, there are conflicting views on the role of LCN2 in pathophysiological processes, with some studies pointing to its neurodeleterious effects, while others indicate neuroprotection. Herein, these various perspectives are reviewed and a comprehensive and cohesive view of the general function of LCN2, particularly in the brain, is provided.
\end{abstract}

(c) 2015 Elsevier Ltd. All rights reserved.

\section{Contents}

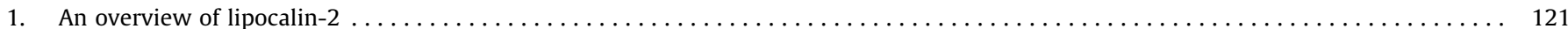

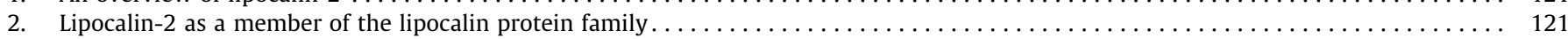

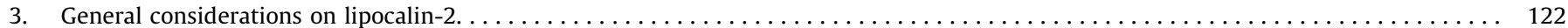

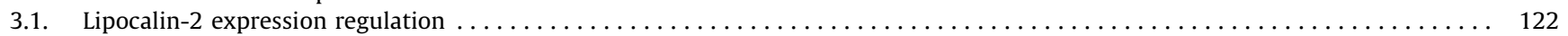

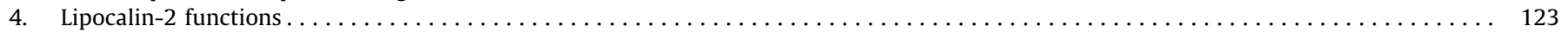

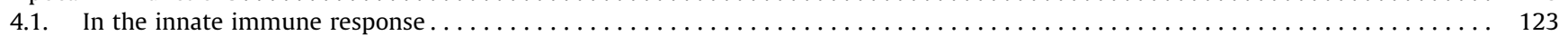

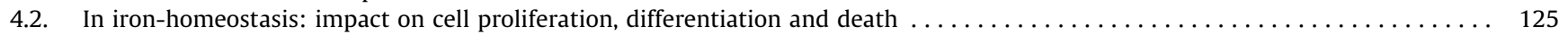

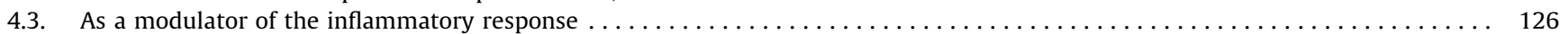

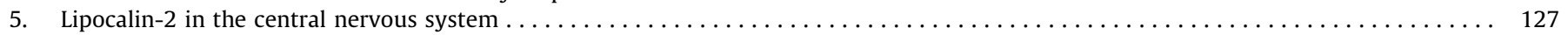

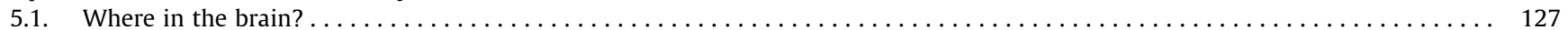

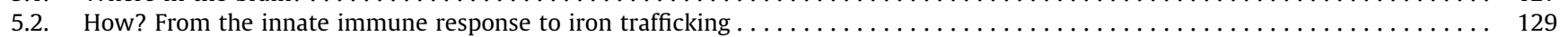

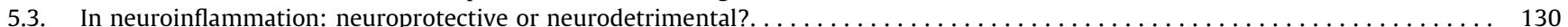

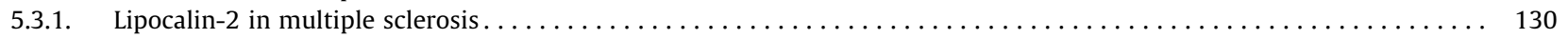

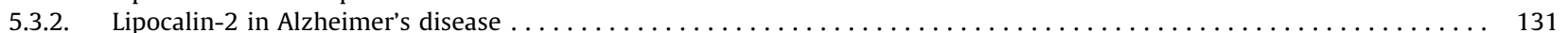

Abbreviations: LCN2, lipocalin-2; 24p3R, solute carrier family 22 member 17; NGAL, neutrophil gelatinase-associated lipocalin; BIM, pro-apoptotic Bcl-2-interacting mediator of cell death; MS, multiple sclerosis; EAE, experimental autoimmune encephalomyelitis; AD, Alzheimer's disease; CP, choroid plexus; CSF, cerebrospinal fluid; LPS, lipopolysaccharide.

* Corresponding author at: Life and Health Sciences Research Institute (ICVS), School of Health Sciences University of Minho, Campus Gualtar, 4710-057 Braga, Portugal. E-mail address: fmarques@ecsaude.uminho.pt (F. Marques). 
6. The promising diagnostic and prognostic value of lipocalin-2 $\ldots \ldots \ldots \ldots 131$

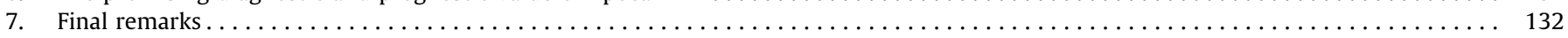

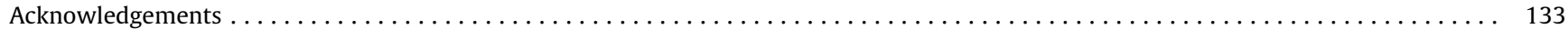

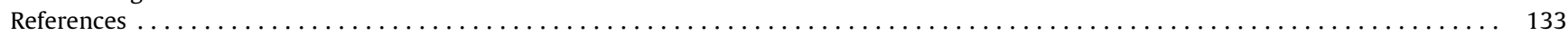

\section{An overview of lipocalin-2}

The need and interest in the identification of molecules that can serve both a physiological role in the organism and allow for the detection of disease onset and progression has emerged over the last decades. Among the proteins identified as key players in health and disease, lipocalin-2 (LCN2) has became increasingly relevant in recent years as a biomarker in several diseases, including acute kidney injury (Kumpers et al., 2010), Alzheimer's disease (AD) (Choi et al., 2011), multiple sclerosis (MS) (Marques et al., 2012) and depression (Naude et al., 2013).

The existence of the knockout mouse for the coding sequence of LCN2 (LCN2-null mice) (Flo et al., 2004) has largely contributed to such findings allowing for the determination of many of the currently known functions of this 25-kDa secreted protein. LCN2null mice are viable and reproduce normally, but display compromised functions at the postnatal level (Flo et al., 2004), albeit LCN2 expression begins already in utero (Mallbris et al., 2002). At postnatal stages, the diverse functions described for LCN2, in physiological and in pathological conditions in different mammalian organ systems, including the central nervous system (CNS) (Fig. 1), called the attention for its considerable interest within the scientific community. Among LCN2's functions, its antimicrobial activity is, undoubtedly, the best described. Specifically, LCN2 acts in the very first steps of antimicrobial defence, as part of the acute-phase response, to sequester bacterial siderophores (bacterial molecules with higher affinity for iron than the host iron-binding proteins) (Flo et al., 2004). Additionally, emerging evidence in the literature associates LCN2 to the modulation of cell physiological processes ( proliferation, differentiation, apoptosis, cell activation and migration), providing a potential important link between physiology and pathology. The strongest evidence for its role in physiological conditions comes from the described involvement in kidney differentiation and in the regulation of epithelial morphogenesis (Yang et al., 2002). Concerning its role in disease, different conditions have been correlated with increased levels of LCN2. Particularly, studies indicate its altered expression in certain types of cancers (Rodvold et al., 2012), coronary diseases

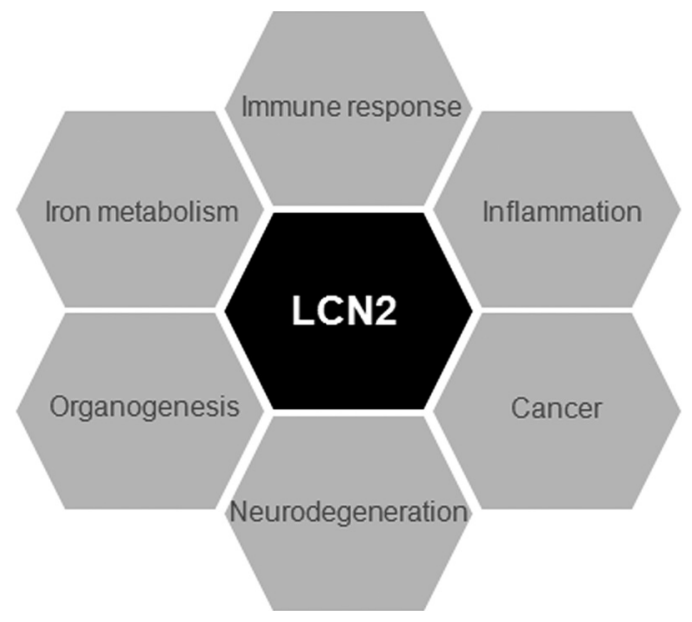

Fig. 1. Representative diagram for the broad and distinct dimensions where LCN2 has described functions. Lipocalin-2 is a secreted protein participating in several biological systems, by mediating processes that are crucial for cellular homeostasis.
(Iqbal et al., 2013), metabolic syndrome (Jang et al., 2012; Yoo et al., 2014), insulin resistance and type 2 diabetes (Yan et al., 2007), chronic kidney disease (Hashikata et al., 2014), autoimmune diseases (Kamata et al., 2012) and in wound repair (Miao et al., 2014). In the brain, the involvement of LCN2 in autoimmune diseases such as MS (Berard et al., 2012; Marques et al., 2012; Nam et al., 2014) and other neurodegenerative disorders such as AD (Choi et al., 2011; Mesquita et al., 2014; Naude et al., 2012) is also suggested.

Altogether, available data indicates a role for LCN2 in several organs in physiological conditions as well as in response to stress or injury. Furthermore, and of notice, LCN2 levels in biological fluids are generally low, being up-regulated and detectable in different stages of several diseases, which strongly indicates the potential of its use as a biomarker of disease onset and progression.

Although there is consensus on the relevance of LCN2 in the acute-phase response, the literature is still contradictory with respect to its role in the pathophysiology of disease. The present review aims to provide a state of the art on the roles of LCN2 in different biological contexts and to explore the current existing conflicting observations. We will first describe, in a general perspective, the well-known functions of LCN2 in the innate immune response associated to infection, iron trafficking and in the modulation of the inflammatory response and, later, focus in more detail on the possible functions of LCN2 in the CNS.

\section{Lipocalin-2 as a member of the lipocalin protein family}

Lipocalin-2 belongs to the lipocalin family, a family of diverse secreted proteins involved in health maintenance and effective in disease prevention (Flower, 1994, 1996). Lipocalins are small (160-180 amino acids in length), soluble and secreted proteins that act as carriers and transporters predominantly of lipophilic/ hydrophobic molecules such as steroids, bilins, retinoids and lipids (Flower, 1994, 1996). For example, apolipoprotein D, $\alpha 1$-microglobulin and purpurin are lipocalins that bind to cholesterol, heme and retinol, respectively (Chakraborty et al., 2012; Flower, 1994). Consequently, several functions have been described for these members of the lipocalin family, including cell division regulation (e.g. $\alpha 1$-microglobulin), cell differentiation, cell-to-cell adhesion and survival (e.g. purpurin) (Flower, 1994). The known ability of lipocalins to form complexes with soluble macromolecules and to bind specific cell-surface receptors is considered to be the basis through which lipocalins modulate their functions (Flower, 1996). Of notice, and unlike most other protein families, members of the lipocalin family share low primary sequence identity, in some case as low as $20 \%$, and membership to this family has been largely determined based on structural similarities (Flower et al., 2000). All members share a common secondary and tertiary structural feature - the so-called "lipocalin fold", which is a cup-shaped cavity where ligands bind (Flower et al., 2000). It is the difference in specific amino acids within this "lipocalin fold" that accounts for the diversity of ligands that lipocalins carry.

Similarly to other lipocalins, LCN2 acts as a carrier/transporter and binds to specific cell-surface receptors, therefore modulating several cellular functions. However, the LCN2 binding cavity is distinct from that of most of other lipocalins, since it is atypically polar and large enough to accommodate macromolecular ligands 
(Goetz et al., 2002). Nevertheless, LCN2 can also weakly bind to some common ligands of lipocalins, including leukotriene B4 and platelet-activating factor (Bratt et al., 1999). Moreover, LCN2 is reported to have high affinity to bind and transport iron but only when iron is complexed with low molecular mass iron-binding ligands, the siderophores (Devireddy et al., 2005; Goetz et al., 2002; Yang et al., 2002). These ligands are small, high-affinity iron chelators, secreted by microorganisms for iron acquisition, but have been recently described to be endogenously produced by mammals (Bao et al., 2010; Devireddy et al., 2010). The capacity of LCN2 to bind iron through siderophores is responsible for its role in the immune response (Flo et al., 2004) and in the regulation of cell proliferation and cell death (Devireddy et al., 2005; Yang et al., 2002). The modulation of cell homeostasis is highly dependent on the interaction of LCN2 with specific cell-surface receptors, namely 24p3R (also known as solute carrier family 22 member 17) (Devireddy et al., 2005) and megalin (Hvidberg et al., 2005), through the regulation of iron cell content (Devireddy et al., 2005). Finally, LCN2 was just recently shown to bind to membrane phosphatidylethanolamine and to induce lipid raft movement in a protein kinase A-dependent manner, with impact in the modulation of sperm maturation (Watanabe et al., 2014). Still unexplored is whether this feature influences specifically sperm maturation or may also be related with other cellular processes such as migration and cell-to-cell interaction.

The specific interaction of LCN2 with iron and its surface cellular receptors, as well as its regulatory expression and clinical significance, will be described and discussed in detail in the following sections.

\section{General considerations on lipocalin-2}

Lipocalin-2 was first identified as the product of an overexpressed gene of murine kidney cells infected with simian virus (Hraba-Renevey et al., 1989). The human protein analogue, on the other hand, was found stored in human neutrophils in close association with matrix metalloproteinase-9 [(MMP-9), a gelatinase secreted by neutrophils for extracellular matrix degradation and remodelling] and showed a high degree of similarity with the deduced sequence of the rat $\alpha 2$-microglobulin related protein (Kjeldsen et al., 1993). At that time, no specific function was attributed to this protein and its covalent association to MMP-9 led to its initial designation as neutrophil gelatinase-associated lipocalin (NGAL) (Kjeldsen et al., 1994; Kjeldsen et al., 1993). Nowadays, while LCN2 is the formal designation (HUGO Gene Nomenclature Committee), it is also known as 24p3, NGAL, oncogene $24 \mathrm{p} 3$, human neutrophil lipocalin, $\alpha 2$-microglobulin related protein, siderocalin and uterocalin. This diversity of designations truly reflects the diverse mechanisms and pathways in which LCN2 has been implicated, and as such, of its potential. Lipocalin-2 is broadly expressed in several tissues and in diverse conditions, with a modulatory induction by specific factors.

\subsection{Lipocalin-2 expression regulation}

In the mouse, LCN2 expression begins in utero during the foetal stage at the level of the proximal tibia and metatarsal (Owen et al., 2008). In 10-days-old foetal mice, LCN2 is strongly expressed in proliferating and prehypertrophic chondrocytes, and remains as such in prehypertrophic and hypertrophic chondrocytes in 17days-old foetal mice (Owen et al., 2008). In humans, the expression of LCN2 during embryonic development, specifically in the skin, has been described to occur in a spatio-temporal manner at 20-24 weeks of gestation in the interfollicular epidermis, with a posterior progression towards the hair follicles (Mallbris et al., 2002). In postnatal stages, evidence derived from mouse tissues indicates that LCN2 is strongly expressed in normal healthy tissues such as the bone marrow, liver, spleen, heart, lungs, kidney and thymus (Aigner et al., 2007). However, as age advances, LCN2's expression progressively declines, particularly in the liver, kidney and spleen (Garay-Rojas et al., 1996). Also, as a component of neutrophils cytoplasmic granules, LCN2 is synthesized during the early stages of neutrophil maturation (Kjeldsen et al., 1993).

Many factors and conditions have been described to trigger the induction of LCN2 in various tissues and cell types. Of interest, the expression of LCN2 is up-regulated in tissues that are more prone to infection such as the mucosal (Kjeldsen et al., 2000) and epithelial (Cowland and Borregaard, 1997; Friedl et al., 1999) barriers, where it behaves as an acute-phase protein. It is also secreted by neutrophils at sites of infection, by adipocytes (Kjeldsen et al., 1993), activated leukocytes and peritoneal cells (Flo et al., 2004), macrophages (Meheus et al., 1993), endothelial (Liu and Nilsen-Hamilton, 1995; Marques et al., 2008) and choroid plexus (CP) epithelial cells (Marques et al., 2008). The regulatory and core elements described to be present in the Lcn2 gene explain, at least partially, how its expression can be regulated by specific molecules (summarized in Table 1). In the mouse, the LCN2 gene has several cis regulatory elements in its $5^{\prime}$-upstream region, including a TATA box-like element (between nucleotides 28 to 23 relative to the transcription start site) and cis binding elements for several transcription factors (Garay-Rojas et al., 1996). Inducers of LCN2 expression include cytokines, growth factors, retinoic acid, glucocorticoids, phorbol esters and lipopolysaccharide (LPS). Among these, LPS has been shown to be the major inducer of LCN2 expression (summarized in Table 1). Specifically, LCN2 is highly expressed in cultured rat peritoneal macrophages (Sunil et al., 2007) and macrophage cell lines (Meheus et al., 1993) after in vitro LPS stimulation. In in vivo experiments, intraperitoneal administration of LPS has been shown to induce LCN2 expression in the CP (Marques et al., 2008), liver and lungs (Sunil et al., 2007). Importantly, the induction of LCN2 expression mediated by LPS stimulation occurs through the activation of the Toll-like receptor (TLR)-4 (Flo et al., 2004). Also in vivo, LCN2 has been shown to act as an acute-phase protein in the liver as a response to the injection of turpentine (Liu and Nilsen-Hamilton, 1995).

As indicated above, LCN2 expression can also be induced by several cytokines and growth factors, which include interleukin (IL)-1 $\beta$ (Cowland et al., 2003), IL-6 (Hamzic et al., 2013), IL-10 (Vazquez et al., 2014), IL-17 (Chiricozzi et al., 2014), IL-22 (Le et al., 2014; Raffatellu et al., 2009), tumour necrosis factor (TNF) (Bu et al., 2006; Landro et al., 2008), insulin-like growth factor-1 (IGF1 ) and transforming growth factor- $\alpha$ (TGF- $\alpha$ ) (Sorensen et al., 2003). The induction of LCN2 expression by such inducers is known to be dependent on the activation of NF- $\kappa \mathrm{B}$ transcriptional activity, with NF- $\kappa B$ being suggested as a positive regulator of LCN2 expression itself (Iannetti et al., 2008). In fact, the Lcn2 gene promoter has an NF- $\mathrm{B}$ response element and four signal transducer and activator of transcription-1 sites (Zhao and Stephens, 2013). Studies using IL-17 and IL-1 $\beta$ indicate that the induction of LCN2 may also require multiple other transcription factors including AP-1 and a CCAAT/enhancer-binding protein site (Cowland et al., 2003; Shen et al., 2006). Similarly, in vitro stimulation of mouse liver cells (Liu and Nilsen-Hamilton, 1995), Lcells (Garay-Rojas et al., 1996) and primary thymocytes (Devireddy et al., 2001) with dexamethasone induces an increase in LCN2 mRNA levels. This specific expression regulation by dexamethasone is mainly explained by the existence of two glucocorticoid responsive core elements in the Lcn2 gene promoter (Garay-Rojas et al., 1996).

Of interest, the expression of LCN2 is also regulated by hormones, including progesterone [suggested to be a negative regulator of LCN2 expression, at least in the uterus (Huang et al., 
Table 1

Summary of the molecules described to modulate the expression of LCN2 and the pathways through which such modulation is known to occur.

\begin{tabular}{|c|c|c|c|c|c|}
\hline $\begin{array}{l}\text { Inductor of } \\
\text { LCN2 expression }\end{array}$ & & $\begin{array}{l}\text { LCN2 } \\
\text { expression }\end{array}$ & Cells/Tissue & $\begin{array}{l}\text { Pathways demonstrated } \\
\text { to be involved }\end{array}$ & References \\
\hline \multirow[t]{3}{*}{ LPS } & & $\uparrow$ & Macrophages & - & Meheus et al. (1993) \\
\hline & & $\uparrow$ & Immortalized epithelial cells & - & Bu et al. (2006) \\
\hline & & $\uparrow$ & Macrophages & TLR4; NF-кB & Sunil et al. (2007) \\
\hline \multirow[t]{3}{*}{ Dexamethasone } & & $\uparrow$ & L cells & GRE & Garay-Rojas et al. (1996) \\
\hline & & $\uparrow$ & Liver cells & & Liu and Nilsen-Hamilton (1995) \\
\hline & & $\uparrow$ & Primary thymocytes & & Devireddy et al. (2001) \\
\hline \multirow[t]{3}{*}{ Oestrogen } & Estradiol & $\downarrow$ & Breast cancer cell lines & ERE & Seth et al. (2002) \\
\hline & $17-\beta$ estradiol & $\downarrow$ & Aortic segments & & Gao et al. (2006) \\
\hline & & $\uparrow$ & Mammary glands & & Seth et al. (2002) \\
\hline \multirow[t]{6}{*}{ Cytokines } & IL-6 & $\uparrow$ & Brain vascular cells & - & Hamzic et al. (2013) \\
\hline & IL-1 $\beta$ & $\uparrow$ & $\begin{array}{l}\text { Immortalized epithelial cells; } \\
\text { embryonic fibroblasts }\end{array}$ & $\begin{array}{l}\text { NF-кB; C/EBP } \delta(C C A A T / \\
\text { enhancer-binding } \\
\text { protein)-binding site }\end{array}$ & $\begin{array}{l}\text { Bu et al. (2006); Cowland et al. (2003); } \\
\text { Shen et al. (2006) }\end{array}$ \\
\hline & IL-22 & $\uparrow$ & $\begin{array}{l}\text { Primary urothelial cells; } \\
\text { intestinal epithelial cells }\end{array}$ & & Le et al. (2014); Raffatellu et al. (2009) \\
\hline & IL-17 & $\uparrow$ & $\begin{array}{l}\text { Epidermis; intestinal epithelial } \\
\text { cells; embryonic fibroblasts }\end{array}$ & & $\begin{array}{l}\text { Chiricozzi et al. (2014); Raffatellu et al. } \\
\text { (2009); Shen et al. (2006) }\end{array}$ \\
\hline & IL-10 & $\uparrow$ & Primary and J774A.1 macrophages & - & Vazquez et al. (2014) \\
\hline & TNF & $\uparrow$ & $\begin{array}{l}\text { Whole blood culture; immortalized } \\
\text { normal epithelial cells }\end{array}$ & NF-кB & Bu et al. (2006); Landro et al. (2008) \\
\hline Retinoic acid & & $\uparrow$ & L cells & - & Garay-Rojas et al. (1996) \\
\hline Insulin & & $\uparrow$ & Adipose tissue explants & MEK/PI-3K pathways & Tan et al. (2009) \\
\hline Growth factors & IGF-1, TGF- $\alpha$ & $\uparrow$ & Primary keratinocytes & - & Sorensen et al. (2003) \\
\hline
\end{tabular}

GRE, glucocorticoid response element; ERE, oestrogen response element.

1999)], and particularly oestrogen, for which Lcn2 contains a response element in the promoter region (Gao et al., 2006; Seth et al., 2002). In in vitro studies, while the stimulation of aortic segments from ovariectomized mice with $17-\beta$ estradiol induces the down-regulation of Lcn2 mRNA levels (Gao et al., 2006), the treatment with estradiol of breast cancer cell lines selected for positive oestrogen receptor leads to sustainable increased expression of LCN2 mRNA (Seth et al., 2002). Also, among other described modulations [reviewed in (Chakraborty et al., 2012)], LCN2 levels were found decreased in mammary glands of ovariectomized mice, which were restored by supplementation with oestrogen (Seth et al., 2002). Finally, other inductors described to promote increased expression of LCN2 include retinoic acid (vitamin A) (Garay-Rojas et al., 1996), which can be of importance for therapeutic proposes, and even insulin, as in vitro studies with adipose tissue explants stimulated with insulin induced the expression of LCN2 (Tan et al., 2009). This ultimate modulation has been associated to the described role of LCN2 in insulin resistance.

The broad expression of LCN2 and its regulation by several factors intimately relates to its functions. For instance, the acute increased concentration of LCN2 in the serum following intraperitoneal injection of LPS is related to its function as an acute-phase protein in the innate immune response to bacterial infection by sequestrating iron (Flo et al., 2004). Moreover, the inducible expression of LCN2 by pro-inflammatory molecules suggests that LCN2 plays an important role in inflammation and inflammatoryrelated diseases. These and other functions will be next further discussed (summarized on Table 2).

\section{Lipocalin-2 functions}

\subsection{In the innate immune response}

The metabolism and division of many pathogenic microorganisms depend on iron availability (Schaible and Kaufmann, 2004). In mammals, iron is predominantly intracellular, tightly bound to proteins such as ferritin; in the circulation, iron is mostly bound to transferrin (Gkouvatsos et al., 2012). To acquire iron, invading pathogens have evolved strategies to survive within such severe iron-poor environments by secreting small iron-binding siderophores (Miethke and Marahiel, 2007). These molecules remove iron from the host's protein-iron complexes, as they have a much higher affinity for iron than the host iron carriers (Miethke and Marahiel, 2007). On the other hand, in order to prevent bacterial iron acquisition, mammals have developed defence mechanisms to "withhold" iron (Cassat and Skaar, 2013; Ganz, 2009). One of such strategies, and as part of the innate immune response, is the production of LCN2 that functions as a chelator of bacterial siderophores (Flo et al., 2004; Goetz et al., 2002). In response to acute bacterial infection, LCN2 is released from the liver and spleen to sequester iron-loaded bacterial siderophores and exert a bacteriostatic effect (Berger et al., 2006). The importance of such response became evident from the lethality that bacterial infection causes in LCN2-null mice (Flo et al., 2004). When exposed to a sublethal dose of a clinical strain of Escherichia coli, H9049, LCN2-null animals develop bacteraemia, sepsis and showed increased lethality, with $80 \%$ of the LCN2-null mice dying within the first $42 \mathrm{~h}$ post-infection (Berger et al., 2006; Flo et al., 2004). When present, LCN2 expression is markedly induced during innate immunity through the activation of TLR4 (Flo et al., 2004) and/or through several pro-inflammatory cytokines (Saiga et al., 2008). Being secreted by neutrophils at sites of infection (Kjeldsen et al., 1994), LCN2 is essential in opposing the scavenge of host iron by bacterial siderophores.

Interestingly, different pathogenic bacteria secrete different types of siderophores (Henderson et al., 2009), but the capacity of LCN2 to bind bacterial siderophores is limited to the catecholatetype (Holmes et al., 2005). Among those are siderophores secreted by E. coli, Salmonella spp. and Klebsiella pneumonia. In infections triggered by these agents, LCN2 has been shown to be protective for the host (Chan et al., 2009; Nairz et al., 2009; Wu et al., 2010). For instance, LCN2 is up-regulated in macrophages in response to Salmonella spp. to confer resistance to the host (Nairz et al., 2009) and LCN2-null animals have impaired lung bacterial clearance upon infection with K. pneumonia (Chan et al., 2009).

Although LCN2 is described to only bind a certain type of siderophores to modulate its bacteriostatic effects, this does not preclude a major role for LCN2 in bacterial infectious that do not produce catecholate-type siderophores. In fact, a role for LCN2 in 
Table 2

Concise description of the functions attributed to LCN2.

\begin{tabular}{|c|c|c|c|}
\hline \multicolumn{4}{|l|}{ LCN2 functions } \\
\hline \multicolumn{4}{|c|}{ Innate immune response (Flo et al., 2004) } \\
\hline Role & Strain & Outcome & References \\
\hline \multirow[t]{3}{*}{$\begin{array}{l}\text { Chelator of bacterial } \\
\text { siderophores }\end{array}$} & E. coli & $\begin{array}{l}\text { LCN2-null animals develop bacteraemia, sepsis and showed } \\
\text { increased lethality ( } 80 \% \text { of the null mice die within the first } \\
42 \mathrm{~h} \text { ) }\end{array}$ & $\begin{array}{l}\text { Berger et al. (2006); } \\
\text { Flo et al. (2004) }\end{array}$ \\
\hline & Salmonella spp. & $\begin{array}{l}\text { LCN2 up-regulated in macrophages to confer resistance to } \\
\text { the host }\end{array}$ & Nairz et al. (2009) \\
\hline & K. pneumonia & $\begin{array}{l}\text { LCN2-null animals present impaired lung bacterial } \\
\text { clearance }\end{array}$ & Chan et al. (2009) \\
\hline \multirow{3}{*}{$\begin{array}{l}\text { Bacterial control by a } \\
\text { siderophore -independent } \\
\text { mechanism }\end{array}$} & S. pneumoniae & $\begin{array}{l}\text { LCN2 limits proliferation of strains that require } \\
\text { enterobactin-like siderophores }\end{array}$ & Nelson et al. (2005) \\
\hline & H. influenzae & & \\
\hline & C. albicans & $\begin{array}{l}\text { LCN2 is induced in an IL-17-dependent manner, but not } \\
\text { essential for host defence }\end{array}$ & Ferreira et al. (2014) \\
\hline Antiplasmodial regulator & Plasmodium & $\begin{array}{l}\text { LCN2 secretion for the control of iron redistribution during } \\
\text { blood-stage malaria }\end{array}$ & Zhao et al. (2012) \\
\hline \multicolumn{4}{|c|}{ Iron homeostasis (Devireddy et al., 2005; Yang et al., 2002) } \\
\hline & Model & Outcome & \\
\hline \multirow{3}{*}{$\begin{array}{l}\text { Inductor of cell proliferation/ } \\
\text { cell differentiation }\end{array}$} & Renal tubular cells & Lcn2 silencing inhibits proliferation & Viau et al. (2010) \\
\hline & Metanephric mesenchymes & $\begin{array}{l}\text { Cellular uptake of the LCN2-iron complex induces epithelial } \\
\text { cell differentiation }\end{array}$ & Yang et al. (2002) \\
\hline & Mouse spermatozoa & Holo-LCN2 is internalized for ferric ion exchange & Elangovan et al. (2004) \\
\hline \multirow[t]{2}{*}{ Inductor of cell death } & Haematopoietic/erythroid cells & $\begin{array}{l}\text { LCN2 promotes apoptosis }{ }^{\mathrm{a}} \text { and inhibits cell survival and } \\
\text { differentiation }\end{array}$ & $\begin{array}{l}\text { Liu et al. (2011); } \\
\text { Miharada et al. (2005) }\end{array}$ \\
\hline & Neonatal myocytes & $\begin{array}{l}\text { LCN2 regulates cardiomyocyte apoptosis by intracellular } \\
\text { iron accumulation }{ }^{\mathrm{b}}\end{array}$ & Xu et al. (2012) \\
\hline \multirow[t]{4}{*}{$\begin{array}{l}\text { Others iron metabolism- } \\
\text { related }\end{array}$} & Anaemia/hypoxia & $\begin{array}{l}\text { LCN2 expression is increased to promote iron utilization/ } \\
\text { mobilization from stores }\end{array}$ & Jiang et al. (2008) \\
\hline & Thalassemia intermedia & $\begin{array}{l}\text { Increased expression of LCN2 for survival facilitation of the } \\
\text { less damaged thalassemic erythroid precursors }\end{array}$ & Patsaoura et al. (2014) \\
\hline & Mouse uterus & $\begin{array}{l}\text { Oestrogen-induced LCN2 expression for iron utilization } \\
\text { during uterine cell growth }\end{array}$ & Stuckey et al. (2006) \\
\hline & $\begin{array}{l}\text { Breast, liver and pancreatic } \\
\text { cancers }\end{array}$ & LCN2 expression for cellular iron trafficking & $\begin{array}{l}\text { Li and Chan (2011); } \\
\text { Torti and Torti (2013) }\end{array}$ \\
\hline \multicolumn{4}{|c|}{ Modulation of the inflammatory response } \\
\hline & Model & Outcome & \\
\hline \multirow[t]{3}{*}{$\begin{array}{l}\text { Anti-inflammatory } \\
\text { modulator }\end{array}$} & Obesity-related inflammation & $\begin{array}{l}\text { Antagonist of the effects of inflammatory molecules (TNF } \\
\text { and IL-6) }\end{array}$ & Zhang et al. (2008) \\
\hline & & Anti-inflammatory regulator in macrophage activation & Guo et al. (2014) \\
\hline & Nephrotoxic nephritis & $\begin{array}{l}\text { Expression in innate immune cells confers protection by } \\
\text { inducing apoptosis }\end{array}$ & Eller et al. (2013) \\
\hline \multirow[t]{8}{*}{$\begin{array}{l}\text { Pro-inflammatory } \\
\text { modulator }^{\mathrm{c}}\end{array}$} & Psoriasis & $\begin{array}{l}\text { Sustained increased levels of LCN2 during pathogenesis, } \\
\text { decreased once the lesions are healed }\end{array}$ & Ataseven et al. (2014) \\
\hline & Autoimmune myocarditis & $\begin{array}{l}\text { LCN2 levels increment according with disease progression, } \\
\text { decreasing upon recovery }\end{array}$ & Ding et al. (2010) \\
\hline & HIV-infected patients & $\begin{array}{l}\text { Decreased serum LCN2 levels, increased upon anti- } \\
\text { retroviral therapy due to decreased neutrophil function }\end{array}$ & Landro et al. (2008) \\
\hline & $\begin{array}{l}\text { Polymorphonuclear } \\
\text { neutrophils }\end{array}$ & $\begin{array}{l}\text { Paracrine chemoattractant indispensable for neutrophil } \\
\text { function during inflammation }\end{array}$ & Schroll et al. (2012) \\
\hline & Heart transplantation & $\begin{array}{l}\text { LCN2 required for the initiation of the inflammatory } \\
\text { response }\end{array}$ & Aigner et al. (2007) \\
\hline & $\begin{array}{l}\text { Mycobacterial pulmonary } \\
\text { infection }\end{array}$ & $\begin{array}{l}\text { Promoter of neutrophil recruitment and regulator of } \\
\text { chemokine production }\end{array}$ & Guglani et al. (2012) \\
\hline & Lupus/arthritis & $\begin{array}{l}\text { Increased LCN } 2 \text { to boost immune cells recruitment for the } \\
\text { inflammatory process initiation }\end{array}$ & $\begin{array}{l}\text { Shashidharamurthy } \\
\text { et al. (2013) }\end{array}$ \\
\hline & Osteoblasts & IL-17-induction of LCN2 to amplify inflammation & Shen et al. (2005) \\
\hline \multirow[t]{2}{*}{ Metabolism regulator $^{d}$} & Obesity & $\begin{array}{l}\text { Increased LCN2 expression correlates with expression } \\
\text { profile of pro-inflammatory cytokines }\end{array}$ & Auguet et al. (2011) \\
\hline & & $\begin{array}{l}\text { LCN2 increased expression in relation to body mass index } \\
\text { and increased activities of MMP- } 2 / 9\end{array}$ & $\begin{array}{l}\text { Catalan et al. (2009); } \\
\text { Yoo et al. (2014) }\end{array}$ \\
\hline
\end{tabular}

a Not directly connected to iron delivery, but shown to be important during acute anaemia.

b As a consequence of the generation of reactive oxygen species.

c In some cases intimately connected to its bacteriostatic role.

d By the control of inflammatory responses.

determining the establishment or maintenance of mucosal colonization by Streptococcus pneumoniae and Haemophilus influenzae has been described (Nelson et al., 2005). An outstanding feature of these bacteria that contrasts with enteric organisms is their independence from siderophore-mediated iron acquisition
(Nelson et al., 2005). As so, the increased expression of LCN2 upon such colonization is suggested to occur to limit the proliferation of competitor species that can colonize the host and that require enterobactin-like siderophores (Nelson et al., 2005). Similarly, LCN2 mediates immunity to fungi such as Candida albicans, as it is 
strongly induced in an IL-17-dependent manner, but surprisingly does not seems to be required for the host overall defence (Ferreira et al., 2014).

The recent discovery of the existence of a mammalian endogenous siderophore, to which LCN2 binds (Bao et al., 2010; Devireddy et al., 2010), was a major breakthrough, providing novel cues on possible functions for LCN2, particularly as an irontrafficking protein in physiological conditions. The described mammalian siderophore is a small metabolic product called catechol (Bao et al., 2010) and, while alone it binds poorly to LCN2, the addition of ferric iron significantly improves its affinity to LCN2 (Bao et al., 2010). In addition, the iron-binding moiety of catechol was described to be 2,5-dihydroxybenzoic acid, which is similar to the bacterial component (2,3-dihydroxybenzoic acid) and even the enzyme responsible for its synthesis, the 3-OH butyrate dehydrogenase-2, is homologue of the bacterial EntA (Devireddy et al., 2010). This finding revealed a feature of intracellular iron homeostasis that is conserved from bacteria to humans, in which LCN2 is involved. Of notice, supplementation with the mammalian siderophore was shown to enhance bacterial growth in vitro, and mice lacking the mammalian siderophore resist to $E$. coli infection (Liu et al., 2014), bringing into light the concept that bacteria are also able to use the mammalian siderophore to scavenge iron from the host (Liu et al., 2014). Nevertheless, and to counteract this use by bacteria, the mammalian host is capable of suppressing 3-OH butyrate dehydrogenase- 2 expression (decreasing the production of the mammalian siderophore), while up-regulating LCN2 expression via TLR4 signalling (Liu et al., 2014). This reciprocal regulation of both LCN2 and the mammalian siderophore is considered to be a protective mechanism to limit microbial access to iron.

In addition to antibacterial and anti-fungal roles, LCN2 was also shown to act as an antiplasmodial defence molecule (Zhao et al., 2012). Described to be up-regulated during malaria infection in mice (Coban et al., 2007), LCN2 was reported to have a pivotal role in controlling parasite levels as well as host innate and adaptive responses during Plasmodium blood-stage malaria infections (Zhao et al., 2012). Importantly, such modulation seems to involve the host iron status, with LCN2 controlling iron redistribution during the infection (Zhao et al., 2012).

Moreover, the existence of a NF- $\mathrm{KB}$-dependent expression of LCN2 (Bu et al., 2006; Matsuo et al., 2007), in line with its involvement in innate and adaptive immune systems, points to an immunomodulatory role of LCN2. In accordance, La Manna and colleagues (2014) observed that the in vitro stimulation of peripheral blood mononuclear cells with LCN2 (both iron-loaded and iron-free forms) potentiated the expression of the human leucocyte antigen $\mathrm{G}$, known to be a tolerogenic molecule (La Manna et al., 2014). The treatment also affected the stimulation of regulatory T-cells, suggesting the putative involvement of LCN2 in the regulation of specific immune pathways (La Manna et al., 2014).

Altogether, new and varied evidence have emerged that point to other roles for LCN2 than those directly related with the acutephase response and control of bacterial growth. For instance, the evidence that LCN2-null mice also present multiple apoptotic defects in haematopoiesis (Liu et al., 2011), impairments in neuronal excitability (Mucha et al., 2011) and in emotional behaviours (Ferreira et al., 2013) opens perspectives for additional roles of LCN2.

\subsection{In iron-homeostasis: impact on cell proliferation, differentiation and death}

The acquisition of iron by cells is critical for cell survival, proliferation and differentiation (Andrews, 2008). Almost all mammalian cells are described to acquire iron by receptormediated endocytosis of iron-loaded transferrin (Garrick and Garrick, 2009). However, the capacity of LCN2 to interact with iron, through a catechol complex, in physiological conditions (Bao et al., 2010; Yang et al., 2002), has paved the way to propose the existence of an LCN2-mediated iron-delivery pathway, with potential impact on cell homeostasis. Interestingly, some observations reinforce LCN2 as an alternative to transferrin in iron trafficking. For instance, hypotransferrinemic mice (Trenor et al., 2000) and atransferrinemic humans (Hamill et al., 1991; Hayashi et al., 1993) have severe defects in haematopoiesis and in CNS development, but display normal development of most epithelial organs, and even mice lacking the transferrin receptor- 1 initiate organogenesis (Levy et al., 1999). In addition, transferrin expression only begins at embryonic day 12 , when organogenesis is already advanced (Gustine and Zimmerman, 1973). This suggests that other proteins, such as LCN2, may provide iron to the cells.

Moreover, the participation of LCN2 in iron-delivery related processes were strengthen upon its identification as an inducer of rat metanephric mesenchyma conversion into epithelia (Yang et al., 2002). Specifically, LCN2 containg iron was identified in the developing mammalian kidney and shown to deliver iron into cells, thus inducing epithelial cell differentiation (Yang et al., 2002). Of interest, LCN2-mediated iron delivery occurred preferentially in the epithelial progenitors at an early stage, while transferrinmediated iron delivery occurs in late epithelial progenitors (Yang et al., 2002). In fact, down-regulation of Lcn2 in mouse renal tubular cells lead to a significant decrease in epidermal growth factor-induced cell proliferation in vitro, and the silencing of LCN2 gene in mice inhibited tubular proliferation (Viau et al., 2010).

The role of LCN2 in iron delivery to cells, via the cellular uptake of the LCN2-iron complex (Yang et al., 2002), requires the existence of cellular receptors that mediate LCN2 uptake with affinity. Hvidberg and colleagues (2005) were the first to demonstrate megalin as one of the cellular receptors for LCN2, since it mediated the endocytosis of LCN2 in polarized epithelia (Hvidberg et al., $2005)$. In the same year, the isolation and identification of $24 p 3 R$ revealed the existence of a fine-tuning mediation of iron content in the cell by LCN2 (Devireddy et al., 2005). Such mediation, irrespectively from the cell type, is largely dependent upon the state of the ligand: iron-containing (holo-) and iron-free (apo-) LCN2 (Devireddy et al., 2005). Specifically, holo-LCN2 binds to $24 \mathrm{p} 3 \mathrm{R}$, is internalized, traffics to endosomes and releases iron from the complex, thereby increasing intracellular iron concentration (Devireddy et al., 2005). By contrast, when apo-LCN2 is internalized upon binding to $24 \mathrm{p} 3 \mathrm{R}$, it chelates iron and transfers it to the extracellular medium, reducing intracellular iron concentration (Devireddy et al., 2005). Importantly, this LCN2-mediated modulation of cell iron content has been shown to impact on cell proliferation and apoptosis, respectively, the later occurring through the pro-apoptotic Bcl-2-interacting mediator of cell death (BIM) (Devireddy et al., 2005; Richardson, 2005).

With the exception of a report questioning the role of LCN2 in the modulation of iron metabolism (Correnti et al., 2012), which suggested that LCN2 does not induce cellular iron efflux, many others studies support the participation of LCN2 in cellular iron homeostasis. For instance, the delivery of iron to spermatozoa, at the caudal epididymis, was demonstrated to occur through the internalization of holo-LCN2, disclosing a physiological role for LCN2 in spermatozoa in the context of protein-ligand complex internalization (Elangovan et al., 2004). Also, LCN2 has been shown to induce apoptosis of haematopoietic cells (Devireddy et al., 2001; Lin et al., 2005; Liu et al., 2011; Miharada et al., 2005) and to inhibit the survival and differentiation of erythroid cells in vitro (Miharada et al., 2005). Although a direct relation to iron levels was not described, this regulation was demonstrated to be important 
during acute anaemia (Miharada et al., 2005). In addition, the observation that LCN2-null mice develop a progressive accumulation of lymphoid, myeloid and erythroid cells strengths the notion that LCN2 is an important regulator of the haematopoietic compartment (Liu et al., 2011).

Similarly, recombinant LCN2 induces cardiomyocyte apoptosis (Xu et al., 2012), an important mechanism of cardiac remodelling leading to heart failure, by promoting intracellular iron accumulation (Xu et al., 2012). Interestingly, this induction of apoptosis triggered by increased intracellular iron content by LCN2 is the opposite of what has been described to occur in other organs (Richardson, 2005). However, in this case, this is considered to occur as a consequence of the generation of reactive oxygen species. In fact, the chemical chelation of free intracellular iron attenuated LCN2-induced caspase-3 activity (Xu et al., 2012). On the other hand, the sustained expression of LCN2 in situations of increased iron utilization, as is the case of anaemia and hypoxia, is suggested to occur as a physiological response to cope with the reduction of iron and to promote iron utilization and mobilization from stores (Jiang et al., 2008). Also, the sustained expression of LCN2, in both mouse models and patients with thalassemia intermedia (an inherited blood disorder), is considered to represent a survival response mechanism in the sense that it can facilitate the maintenance of the few but still functional erythroid precursors, or as a consequence of the abnormal iron regulation in the disease. However, no correlation has been found between LCN2 levels and either the parameters of erythropoiesis (haemoglobin, foetal haemoglobin, reticulocytes and soluble transferrin receptor), or of iron storage (ferritin and nontransferrin-bound iron) (Patsaoura et al., 2014). Likewise, the temporally coordinated induction of LCN2 expression, among other iron homeostasis genes, was observed to occur by oestrogen in the mouse uterus, evidencing an important role of iron metabolism during sex steroid hormone-induced uterine cell growth and differentiation (Stuckey et al., 2006).

The additional reported expression of LCN2 in a number of cancers (Li and Chan, 2011), including breast, liver and pancreatic cancer, has been considered to occur as a source of iron for cells to proliferate (Torti and Torti, 2013). With descriptions ranging from a pro- to an anti-cancer role, LCN2 is engaged in key events known to contribute to malignancy (apoptosis, proliferation and invasion). For instance, transfection of MCF7 human breast cancer cells with human LCN2 expression constructs increases cell proliferation (Fernandez et al., 2005) and potentiates angiogenesis (Yang et al., 2013). In accordance, inhibition of LCN2 reduces breast tumorigenesis (Sun et al., 2011), whereas in the case of the colorectal cancer, LCN2 expression has been either correlated with a decreased overall survival of patients (Sun et al., 2011) but also with reduced metastasis (Lee et al., 2006). Nevertheless, it is important to highlight that in the majority of the above-described reports, it is not clear whether the observed effects for LCN2 are directly related with alterations in the intracellular iron levels.

\subsection{As a modulator of the inflammatory response}

Several studies highlight the increased production of LCN2 upon diverse pro-inflammatory stimuli. In fact, the acute upregulation of LCN2 suggests its involvement in inflammatory diseases, either by contributing to the progression of the inflammatory state or, on the contrary, to the development of an anti-inflammatory state.

In addition, in some cases, the increased expression of LCN2 closely accompanies the disease process, which lead to the suggestion of its potential usefulness to monitor disease progression (further discussed in section 6). For instance, the described increased levels of LCN2 in the skin of patients with psoriasis, where chronic inflammation plays a role in disease pathogenesis, is followed by a decrease in LCN2 levels, once the lesions are healed (Ataseven et al., 2014). In addition, serum LCN2 levels are increased in animal models of autoimmune myocarditis at an early stage of the disease, and remain high during the inflammatory stage, but decreased upon recovery (Ding et al., 2010). In the case of lymphopenic HIV-infected patients, serum LCN2 levels are low and increase upon anti-retroviral therapy (Landro et al., 2008). In the case of HIV, the low levels of serum LCN2 are considered to reflect a decrease in neutrophil number and function, since a positive correlation between neutrophil counts and LCN2 levels was observed (Landro et al., 2008).

Consistent with its role in anti-inflammatory responses, LCN2 has been shown to antagonize the effects of TNF on adipocytes and macrophages, and to attenuate the stimulatory effects of LPS on the gene expression of IL- 6 and monocyte chemoattractant protein-1 in adipocytes (Zhang et al., 2008). Moreover, LCN2-null mice were described to display an up-regulated expression of the M1 macrophage marker (Cd11c) and a down-regulation of the M2 marker (arginase 1) in adipose tissue and liver after a high-fat diet feeding (Guo et al., 2014). Also, LCN2-null bone marrow-derived macrophages were more sensitive to LPS stimulation and presented an up-regulation of pro-inflammatory markers expression, which was attenuated upon treatment with recombinant LCN2 (Guo et al., 2014). Altogether, this suggests that LCN2 plays a role as an anti-inflammatory regulator in macrophage activation. In addition, in murine nephrotoxic serum nephritis, an inflammatory kidney disease characterized by increased infiltration of leukocytes, LCN2 is considered to be an endogenous inhibitor of inflammation, since its expression in innate immune cells is protective by inducing apoptosis of macrophages and by limiting cytokine production via TLR2 signalling (Eller et al., 2013).

On the contrary, the role of LCN2 as a pro-inflammatory modulator has also been described and is mainly related to its already described role as a bacteriostatic protein. The inflammatory status that underlies a defence response against pathogens is considered protective and necessary to remove, control and/or neutralize injurious microorganisms. Indeed, the acute inflammation triggered initially represents the first line of defence in response to invading pathogens or to tissue damage. Under this circumstance, and at low bacterial density, it is well established that LCN2 exerts its iron-depletion strategies for bacterial proliferation. As bacterial density increases, LCN2 becomes a pro-inflammatory molecule, serving as a signal of uncontrolled bacterial replication to induce chemokines' expression that, in turn, potentiates the influx of neutrophils into the site of infection (Bachman et al., 2009). As such, LCN2 was considered a paracrine chemoattractant indispensable for neutrophil function in inflammation (Schroll et al., 2012). The addition of recombinant LCN2 to primary cultures of human and murine polymorphonuclear neutrophils significantly stimulated neutrophil migration, while a significantly reduced neutrophil chemotactic activity and impaired cellular adhesion is observed in cells obtained from LCN2-null mice (Schroll et al., 2012). In the same line of evidence, the number of infiltrating granulocytes, after reperfusion, in murine heart transplantation, was described to be reduced in LCN2-null grafts, suggesting a role for LCN2 in the initiation of the inflammatory response (Aigner et al., 2007). Similarly, during mycobacterial pulmonary infection, LCN2 was shown to restrain inflammation by inhibiting inflammatory chemokines production but at the same time to promote neutrophil recruitment (Guglani et al., 2012). In addition, the increased levels of LCN2 in autoimmune disorders, such as the case of lupus and arthritis, boost the recruitment of immune cells to the site of inflammation, a process essential for the initiation, perpetuation, and resolution of the inflammatory processes (Shashidharamurthy et al., 2013). 
Additionally, it is hypothesized that LCN2 is released by granulocytes at sites of inflammation and, therefore, mediates local tissue injury (Li and Chan, 2011). This specific contribution derives from the description of LCN2 secretion in tissue damage also following ischaemia, namely to recruit and chemoattract other immune cells that participate in the inflammatory response (Aigner et al., 2007). Also the description that LCN2 produced at the sites of inflammation can act as an inducer of apoptosis may also be contributing for local tissue injury. In cultured osteoblasts, LCN2 induction by IL-17 was observed to promote cell apoptosis and to modulate subsequent inflammatory events (Shen et al., 2005). Both are considered to work synergistically to amplify inflammation.

In parallel, more modulatory effects have been described for LCN2 under inflammatory conditions, some through mechanisms that are still to be disclosed. Among these, exercise-induced inflammation modulates bone marrow homeostasis leading to an increase in leucocyte turnover and a decrease in erythroid compartment (Spiropoulos et al., 2010). Of interest, it seems that LCN2 is the main factor that regulates the production and mobilization of erythroid progenitor cells (Spiropoulos et al., 2010). In a different context, the sustained expression of LCN2 upon liver damage is considered to be a reliable indicator of damage and has significant hepatoprotective effects (BorkhamKamphorst et al., 2013). Despite the absence of correlation between human LCN2 serum levels and the degree of liver fibrosis, a positive correlation with the inflammatory status was observed (Borkham-Kamphorst et al., 2013). The proteomic profiling of LCN2-null mice under normal conditions and after exposure to inflammatory stimuli (LPS) reveals several altered proteins that are described to have functions in detoxification, metabolism of nutrients and in cell adhesion, thus suggesting an essential function for LCN2 in liver homeostasis and in the onset of inflammatory responses (Labbus et al., 2013).

Remarkably, LCN2 is also involved in the regulation of metabolism, through the control of the inflammatory response. The increased production of LCN2 in the adipose tissue and in the liver as a response to metabolic stress and to cytokines, points for the involvement of LCN2 in adipocyte metabolism and inflammation (Zhang et al., 2014). In fact, a function for LCN2 in insulin resistance and glucose metabolism has already been described. Suggested by some authors as a potential adipokine (Yoo et al., 2014; Zhang et al., 2008), LCN2 was found increased in serum of obese patients and in adipose tissue and liver of obese mice (Zhang et al., 2008) as well as in a metabolic syndrome rat model (Yoo et al., 2014). Importantly, such levels are strongly correlated with the expression profile of pro-inflammatory cytokines (Auguet et al., 2011) and of other circulating markers of inflammation (Yoo et al., 2014). Also, the increased adipose tissue expression of LCN2 in obesity was correlated to body mass index (Yoo et al., 2014) and to increased activities of both MMP-2 and MMP-9, reinforcing its potential participation in the low-grade chronic inflammation associated with obesity (Catalan et al., 2009). Moreover, LCN2 was also shown to impact in the energy metabolism, even in the absence of increased inflammation, since exogenous recombinant LCN2 is able to increase glucose production in hepatocytes (Yan et al., 2007). The precise function and relevance of LCN2 in obesity and in energy metabolism is, nonetheless, quite controversial since studies with LCN2-null mice were inconclusive. In one study, LCN2-null mice were shown to be protected from diet-induced obesity, insulin resistance and inflammation by modulating 12lipoxygenase and TNF levels in adipose tissue (Law et al., 2010). In another one, LCN2 absence significantly potentiated diet-induced obesity, dyslipidemia, fatty liver disease, and insulin resistance (Guo et al., 2010). Also, LCN2 expression is differentially regulated in diabetes, since its levels were found to be increased in human subjects in response to insulin infusion (Tan et al., 2009); still, whether this increase reflects a protective response or contributes to disease progression is not yet known.

In summary, there is still some inconsistency regarding the effects of LCN2 in the inflammatory response. Such contradictions are even more marked with respect to brain diseases, which will be next discussed in detail.

\section{Lipocalin-2 in the central nervous system}

In the CNS, as in the immune/inflammatory response, the functions of LCN2 are similarly controversial. A first report described its up-regulation in whole brain homogenates in response to peripheral turpentine-induced inflammation (Liu and Nilsen-Hamilton, 1995). Later descriptions demonstrated LCN2 up-regulation in the brain upon a peripheral inflammatory stimulus (with LPS) (Marques et al., 2008) and in animal models of CNS diseases such as experimental autoimmune encephalomyelitis (EAE) (Marques et al., 2012), AD (Naude et al., 2012) and in spinal cord injury (Poh et al., 2012; Rathore et al., 2011). In this context, LCN2 is likely to be engaged in identical mechanisms as those described in the periphery such as in the modulation of the innate immune response (through siderophore binding and iron homeostasis), in the balance between pro- and anti-inflammatory responses, in cellular activation and cellular migration, and, eventually, also in mechanisms still undetermined or not clearly identified (Lee et al., 2011; Lee et al., 2009).

\subsection{Where in the brain?}

In the brain, LCN2 expression is described to occur mainly in response to an injury or inflammatory status (Ip et al., 2011; Marques et al., 2008; Thouvenot et al., 2006), but the basal and physiological expression of LCN2 was also described to occur in specific regions of the adult rat brain (Chia et al., 2011). Particularly, Chia and colleagues (2011) showed that low levels of LCN2 mRNA and protein expression are detected in most regions of the normal adult brain, except for the olfactory bulb, brainstem and cerebellum, where the expression levels are higher (Chia et al., 2011). Single and double immunostaining revealed the presence of LCN2 in astrocytes in these regions in the normal brain (Chia et al., 2011). However, the presence of LCN2 in the brain, under physiological conditions, is quite controversial since other authors have reported the absence of labelling or expression (Ip et al., 2011; Marques et al., 2012; Mesquita et al., 2014). Still, LCN2 sustained expression is accepted to occur when an injury is imposed to the CNS or when a CNS disease is installed. In such cases, LCN2 expression is restricted to the affected brain region, although controversy exists on the type of cells producing it (Table 3). In initial reports, LCN2 was shown to be induced after an acute peripheral injection of LPS at the barriers of the brain, both in the CP epithelial cells and in the endothelial cells of the capillaries that irrigate the brain parenchyma (Marques et al., 2008). Of interest, not all CP epithelial cells produce LCN2 simultaneously and this secretion is not observed when the peripheral stimulus is repeated (Marques and Sousa, 2015) or become chronic, such as in the EAE mouse model of MS (Marques et al., 2012). In the later cases, LCN2 expression in the $\mathrm{CP}$ derives from infiltrating neutrophils (Marques et al., 2012) (Fig. 2). Yet, it is now know that LCN2 expression in the brain at inflammatory conditions is not restricted to the barriers, but extends to the brain parenchyma. For instance, in the EAE mice model, LCN2 was found in activated astrocytes particularly in brain regions typically affected in MS patients (Marques et al., 2012) (Fig. 2). Notably, the production of LCN2 by astrocytes and infiltrating neutrophils in the EAE mice likely contributes to its presence in the cerebrospinal fluid (CSF) during the active phases 


\begin{tabular}{|c|c|c|c|c|c|c|c|}
\hline & \multirow[t]{2}{*}{ Model } & \multicolumn{2}{|l|}{ LCN2 expression } & \multirow{2}{*}{$\begin{array}{l}\text { 24p3R expression } \\
\text { Brain cells }\end{array}$} & \multirow{2}{*}{$\begin{array}{l}\text { LCN2-null mice } \\
\text { phenotype }\end{array}$} & \multirow[t]{2}{*}{ Proposed role for LCN2 } & \multirow[t]{2}{*}{ References } \\
\hline & & Brain region & Brain cells & & & & \\
\hline \multirow[t]{2}{*}{ Ischaemia } & Transient focal cerebral ischaemia & Peri-infarct cortex & Neurons $^{\mathrm{a}}$ & - & - & Help-me signal for glial activation & Xing et al. (2014) \\
\hline & $\begin{array}{l}\text { Transient middle cerebral artery } \\
\text { occlusion; Hypoxic-ischaemic } \\
\text { brain injury }\end{array}$ & $\begin{array}{l}\text { Ipsilateral } \\
\text { hemispheres }\end{array}$ & Astrocytes, microglia & $\begin{array}{l}\text { Neurons, astrocytes, } \\
\text { endothelial cells }\end{array}$ & $\begin{array}{l}\text { Decreased inflammatory } \\
\text { phenotype }\end{array}$ & Glial activation & Jin et al. (2014b) \\
\hline \multirow[t]{8}{*}{ Neuroinflammation } & LPS-induced neuroinflammation & Whole brain & $\begin{array}{l}\text { Endothelial cells, astrocytes, } \\
\text { microglia }\end{array}$ & - & $\begin{array}{l}\text { Reduced glial activation } \\
\text { and neurotoxicity }\end{array}$ & $\begin{array}{l}\text { Promoter of neurotoxic glial } \\
\text { activation, neuroinflammation }\end{array}$ & Jin et al. (2014a) \\
\hline & & $\begin{array}{l}\text { Brain barriers, } \\
\text { brain parenchyma }\end{array}$ & $\begin{array}{l}\text { CP epithelial cells, endothelial } \\
\text { cells }\end{array}$ & - & - & Part of the innate immune response & $\begin{array}{l}\text { Marques et al. } \\
\text { (2008) }\end{array}$ \\
\hline & $\begin{array}{l}\text { In vitro CP epithelial cells } \\
\text { stimulated with LPS }\end{array}$ & - & CP epithelial cells & - & - & $\begin{array}{l}\text { Neuronal growth, differentiation } \\
\text { and function }\end{array}$ & $\begin{array}{l}\text { Thouvenot et al. } \\
\text { (2006) }\end{array}$ \\
\hline & $\begin{array}{l}\text { Transgenic rats expressing mutant } \\
\text { human TDP- } 43\end{array}$ & $\begin{array}{l}\text { Forebrain, } \\
\text { spinal cord }\end{array}$ & Astrocytes & $\begin{array}{l}\text { Reactive astrocytes, } \\
\text { neurons }\end{array}$ & - & Neuronal death & Bi et al. (2013) \\
\hline & Intracerebral haemorrhage & $\begin{array}{l}\text { Ipsilateral basal } \\
\text { ganglia, cortex }\end{array}$ & Astrocytes, some neurons & - & - & Modulation of iron homeostasis & Dong et al. (2013) \\
\hline & LPS-induced endotoxemia & $\begin{array}{l}\text { Whole brain, } \\
\text { parenchyma, } \\
\text { brain barriers }\end{array}$ & $\begin{array}{l}\text { Endothelium, microglia, } \\
\text { CP epithelial cells }\end{array}$ & Neurons, CP & $\begin{array}{l}\text { Similar inflammatory } \\
\text { response to controls }\end{array}$ & $\begin{array}{l}\text { Not an essential modulator of } \\
\text { gliosis in response to LPS in vivo }\end{array}$ & Ip et al. (2011) \\
\hline & Kainate-induced excitotoxic model & Hippocampus & Astrocytes & - & - & Iron transport & Chia et al. (2011) \\
\hline & Spinal contusion injury & $\begin{array}{l}\text { Spinal cord, } \\
\text { brain barriers }\end{array}$ & $\begin{array}{l}\text { Astrocytes, neurons, } \\
\text { endothelial cells }\end{array}$ & Astrocytes, neurons & $\begin{array}{l}\text { Improved recovery } \\
\text { from contusion }\end{array}$ & Inflammatory regulator & $\begin{array}{l}\text { Rathore et al. } \\
(2011)\end{array}$ \\
\hline Infection & West Nile virus encephalitis & Whole brain & $\begin{array}{l}\text { Ependymal cells, astrocytes, } \\
\text { CP epithelial cells, neurons, } \\
\text { parenchymal cells }\end{array}$ & - & $\begin{array}{l}\text { Tissue viral load } \\
\text { and survival } \\
\text { similar to controls }\end{array}$ & $\begin{array}{l}\text { Dispensable as an } \\
\text { immunoregulatory factor }\end{array}$ & Nocon et al. (2014) \\
\hline \multirow[t]{3}{*}{ Pain } & $\begin{array}{l}\text { Complete Freund's adjuvant } \\
\text { injection }\end{array}$ & Hindpaw & Microglia & Microglia & $\begin{array}{l}\text { Mechanical allodynia } \\
\text { diminished }\end{array}$ & $\begin{array}{l}\text { Central sensitization and } \\
\text { nociceptive behaviour }\end{array}$ & Jha et al. (2014) \\
\hline & $\begin{array}{l}\text { Formalin injection; peripheral } \\
\text { nerve injury }\end{array}$ & - & - & - & $\begin{array}{l}\text { Nociceptive behaviour } \\
\text { attenuated }\end{array}$ & & Jha et al. (2013) \\
\hline & Spared nerve injury & Spinal cord & Neurons & Neurons, microglia & Less pain sensitivity & Mediator of neuropathic pain & Jeon et al. (2013) \\
\hline \multirow[t]{3}{*}{ MS } & Chronic model & Spinal cord & Astrocytes & Astrocytes, microglia & $\begin{array}{l}\text { Disease phenotype } \\
\text { attenuated }\end{array}$ & $\begin{array}{l}\text { Modulator of autoimmune } \\
\text { inflammation }\end{array}$ & Nam et al. (2014) \\
\hline & Relapsing-remitting EAE model & $\begin{array}{l}\text { Brain barriers }{ }^{\mathrm{b}} \text {, } \\
\text { cerebellum, } \\
\text { brain stem }\end{array}$ & CP stromal cells, astrocytes & - & - & Putative molecule for MS diagnosis & $\begin{array}{l}\text { Marques et al. } \\
\text { (2012) }\end{array}$ \\
\hline & Relapsing-remitting EAE model & Spinal $\operatorname{cord}^{\mathrm{a}, \mathrm{c}}$ & Astrocytes & Astrocytes, microglia & $\begin{array}{l}\text { Disease severity } \\
\text { increased }\end{array}$ & Modulator of EAE pathogenesis & $\begin{array}{l}\text { Berard et al. } \\
(2012)\end{array}$ \\
\hline \multirow[t]{2}{*}{$\mathrm{AD}$} & In vitro TNF stimulation & $\mathrm{a}, \mathrm{b}$ & $\begin{array}{l}\text { Primary culture neurons, } \\
\text { astrocytes, and microglia }\end{array}$ & - & - & $\begin{array}{l}\text { Sensitization of nerve cells to } \beta \text { - } \\
\text { amyloid toxicity }\end{array}$ & $\begin{array}{l}\text { Naude et al. } \\
\text { (2012) }\end{array}$ \\
\hline & In vitro $\mathrm{A} \beta$ cellular stimulation & & CP epithelial cells, astrocytes & $\begin{array}{l}\text { CP epithelial cells, } \\
\text { astrocytes, neurons }\end{array}$ & $\begin{array}{l}\text { Increased cellular } \\
\text { viability }\end{array}$ & Required to mediate $A \beta$ toxicity & $\begin{array}{l}\text { Mesquita et al. } \\
\text { (2014) }\end{array}$ \\
\hline \multirow[t]{2}{*}{ Behaviour } & $\begin{array}{l}\text { Behavioural characterization of } \\
\text { LCN2-null mice }\end{array}$ & & - & - & $\begin{array}{l}\text { Emotionally altered, } \\
\text { cognitive impaired; } \\
\text { decreased LTP }\end{array}$ & $\begin{array}{l}\text { Modulator of synaptic activity and } \\
\text { behaviour }\end{array}$ & $\begin{array}{l}\text { Ferreira et al. } \\
\text { (2013) }\end{array}$ \\
\hline & Acute restraint stress & & Neurons, astrocytes & - & Stress-induced anxiety & Regulator of neuronal excitability & $\begin{array}{l}\text { Mucha et al. } \\
\text { (2011); Skrzypiec } \\
\text { et al. (2013) }\end{array}$ \\
\hline
\end{tabular}

CP, choroid plexus; CSF, cerebrospinal fluid; LPS, lipopolysaccharide; MS, multiple sclerosis; EAE, experimental autoimmune encephalomyelitis; LTP, long-term potentiation; AD, Alzheimer’s disease.

a Also in post-mortem human brain tissue.

b Also detected in CSF of patients.

$c$ In serum and CSF of patients. 


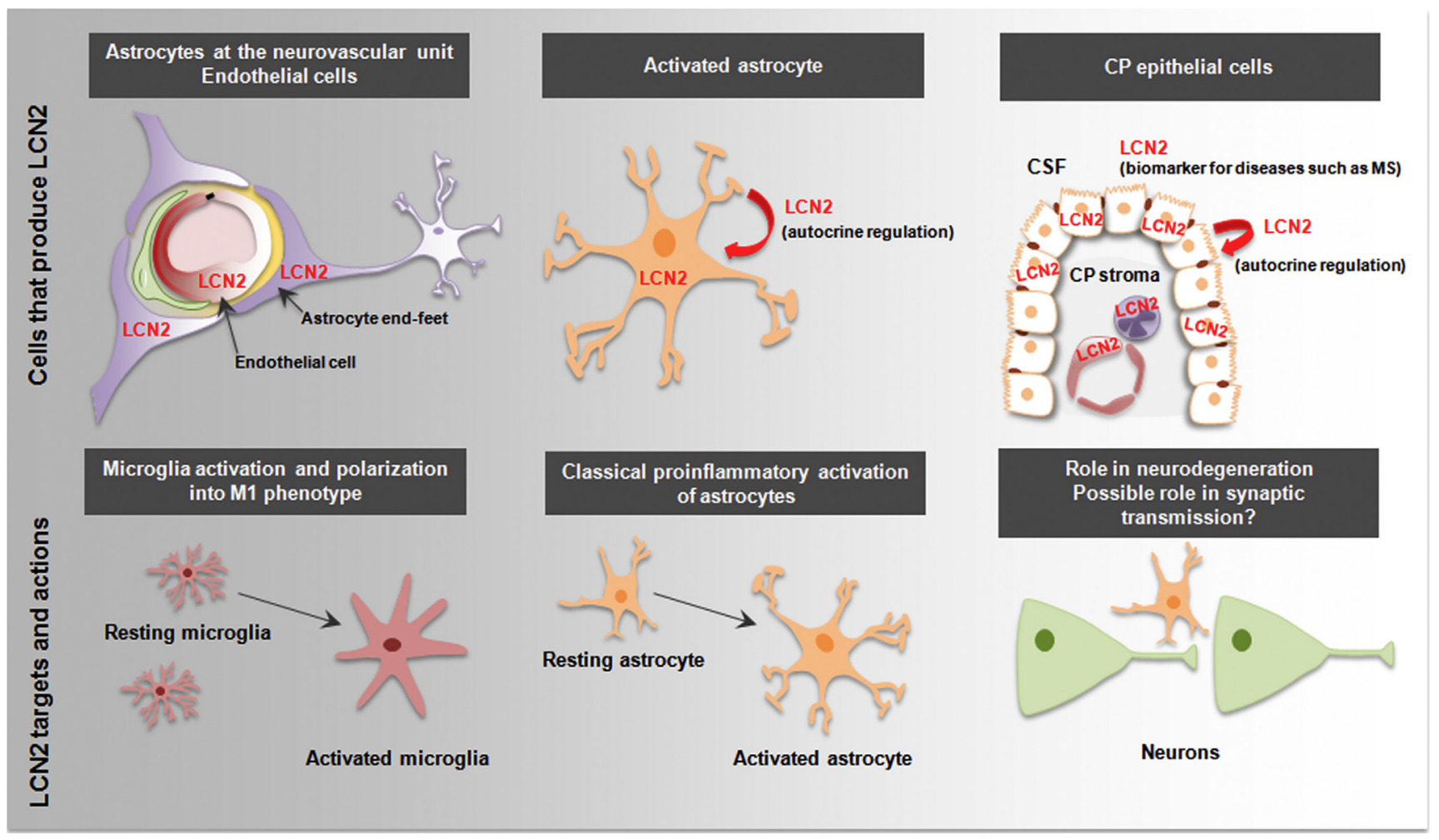

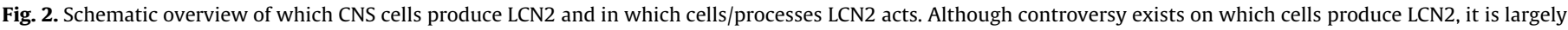

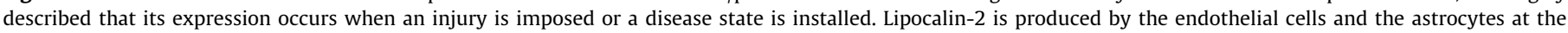

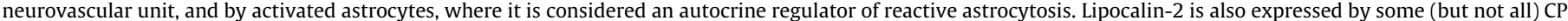

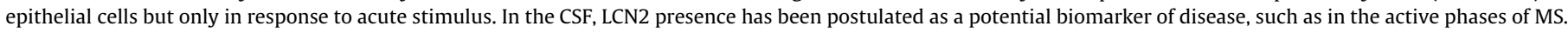

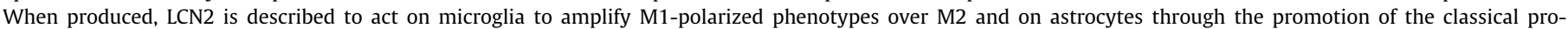

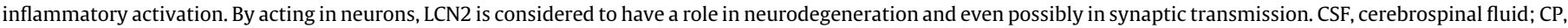
choroid plexus; MS, multiple sclerosis.

of disease (Marques et al., 2012). In addition, other authors have shown that in the ischaemic brain and after transient middle cerebral artery occlusion, LCN2 is predominantly produced by the brain endothelium and by astrocytes, whereas its receptor (24p3R) is expressed in neurons, astrocytes and endothelial cells (Jin et al., 2014b) (Table 3). Similarly, increased levels of LCN2 mRNA and protein were found in the $\mathrm{CP}$, vascular endothelium, macrophage/ microglia and astrocytes in an animal model of West Nile virus encephalitis (Nocon et al., 2014). Interestingly, in this study, the authors also evidenced that some neuronal subsets contained LCN2 protein, but no detectable mRNA expression (Nocon et al., 2014). Again, in a rat animal model of brain injury after intracerebral haemorrhage, LCN2 expression was found markedly increased in the ipsilateral basal ganglia and cortex, with most LCN2 positive cells being astrocytes (Dong et al., 2013) (Table 3). The precise identification of the brain cells that express, secrete and take up LCN2 are yet to be clearly defined, since contradictory reports exist. Most authors, as mentioned until now and including our group, were unable to detect LCN2 expression by neurons or microglial cells in the brain parenchyma (Marques et al., 2009); however, few studies suggest that indeed both cell types are able to produce it. Specifically, when assessing the role of LCN2 in the pathogenesis of neuropathic pain using a mouse model of spared nerve injury, LCN2 was detected in neurons of the spinal cord, simultaneously with the expression of the $24 \mathrm{p} 3 \mathrm{R}$ in spinal neurons and microglia (Jeon et al., 2013). Additionally, LCN2 was described as one of the most highly up-regulated transcripts detected by microarray analysis in the mouse hippocampus (Mucha et al., 2011) and in the amygdala (Skrzypiec et al., 2013), after an acute restraint protocol of stress. In these studies, LCN2 expression was found in the pyramidal cell layers of CA1-CA3 and in the granule cell layers of the dentate gyrus of the hippocampus, co-localizing with the neuronal marker NeuN (Mucha et al., 2011). At the nucleus of the basolateral amygdala, LCN2 was shown to colocalize mostly with neurons and, to a lesser extent, with the glial fibrillary acidic protein astrocyte marker (Skrzypiec et al., 2013). Furthermore, the presence of LCN2, and its release by neurons, was described in post-mortem human brain samples of stroke patients, compared to the contralateral cortex, and in the rat animal model of focal cerebral ischaemia (Xing et al., 2014).

Of relevance, the controversy of whether LCN2 is produced by neuronal cells also persists even in in vitro studies. Experiments have demonstrated the expression of LCN2 by neurons in response to TNF (Naude et al., 2012) and after oxygen-glucose deprivation (Xing et al., 2014), while others showed no expression by these cells in response to amyloid beta (A $\beta$ ) or LPS (Mesquita et al., 2014). This inconsistency may be related to the different stimuli or type of insult applied or possibly due to neuron-enriched culture contamination by astrocytes that can easily occur (Mesquita et al., 2014). Interestingly, in vitro studies showed that LCN2 expression by astrocytes occurs only when they are reactive (Bi et al., 2013), corroborating the described in vivo expression of LCN2 by astrocytes only in diseased brain regions, as we will further discuss.

\subsection{How? From the innate immune response to iron trafficking}

When the levels of LCN2 were reported to be increased at the brain barriers in response to peripheral administration of LPS, a role in protecting the brain from invading microorganisms, 
through sequestration of iron, was suggested (Marques et al., 2008). This argued in favour of a LCN2 bacteriostatic action in the CNS, similarly to that described for the periphery (Flo et al., 2004). Still, the relevance of LCN2 production by the brain barriers will depend on the pathogen that is invading the CNS since, for instance, the function of LCN2 in the host response to West Nile virus encephalitis infection was shown to be dispensable as the infected brains of LCN2-null and WT mice contained similar numbers of infiltrating cells and no differences in tissue viral loads or survival was observed (Nocon et al., 2014).

As mentioned before, in addition to $\mathrm{CP}$ epithelial cells and to endothelial cells (Marques et al., 2008), some have described the production of LCN2, at the brain parenchyma, by neurons (Mucha et al., 2011; Naude et al., 2012) and by microglia (Ip et al., 2011; Naude et al., 2012) although this is controversial. Nevertheless, consensus exists on the synthesis of LCN2 by astrocytes, which are considered the major producers of LCN2 in the brain (Bi et al., 2013; Chia et al., 2011; Marques et al., 2012). As such, its secretion is assumed to be one of the mechanisms through which astrocytes interact with neurons and regulate neuronal homeostasis. This possible role in neuronal homeostasis pertains to iron transport by LCN2. This is conceivable because neurons constitutively express 24p3R even in physiological conditions (Ip et al., 2011; Rathore et al., 2011). Indeed, the iron-binding capability of LCN2 has been shown to be a key element in the regulation of dendritic spine density and morphology (Mucha et al., 2011). Specifically, this type of regulation was demonstrated to occur in an iron-dependent manner, since in vitro treatment of hippocampal neurons with holo-LCN2 caused a decrease in spine density but treatments with apo-LCN2 further potentiate those processes (Mucha et al., 2011). Moreover, both apo- and holo-LCN2 affected spines shape, by increasing the proportion of the thin type and decreasing the density of mushroom spines, being again the effects with apo-LCN2 more pronounced (Mucha et al., 2011). In this work, Mucha et al. (2011) also showed that this effect on spine plasticity is due to a decrease in actin's mobile fraction, which is a component of the spine cytoskeleton and that regulates its shape (Mucha et al., 2011). It is generally accepted that mushroom spines are mature spines and that are implicated in the maintenance of established neuronal networks and long-term memory ("memory spines") and, although LCN2 is certainly not the only modulator of dendritic spine shape, this peculiar modulation of actin mobility may have an impact on structural plasticity and behaviour. In fact, disruption of Lcn2 expression in mice promotes increased anxiety, depressivelike behaviour and mild spatial reference memory impairments (Ferreira et al., 2013). Importantly, these behavioural alterations are concomitant with significant alterations in the morphology of hippocampal neurons and spine density, along the dorsal-ventral axis (Ferreira et al., 2013). Regarding this, the absence of LCN2 promotes neuronal hypertrophy at the ventral hippocampus, with a significant atrophy in neurons at the dorsal division and a decrease in the proportion of mushroom type spines (Ferreira et al., 2013). Similarly, in response to stress, the ablation of LCN2 revealed to be deleterious by promoting stress-induced increase in spine density, which correlated with a higher excitability of CA1 neurons and stress-induced anxiety (Mucha et al., 2011). Nonetheless, since the brain responds differently depending on the presence of an acute or chronic stressful stimulus, the strategy of LCN2-null mice to cope with different stress paradigms requires further detailed studies.

Still to be unravelled is whether, similar to what occurs in kidney development (Yang et al., 2002), LCN2 is able to modulate cell proliferation in the brain through iron trafficking. This possible modulation can be crucial for brain homeostasis maintenance, with further impact in the neurogenic niches in response to injury. Interestingly, the involvement of LCN2 in neurodegenerative disorders, such as AD, where iron is a key player, has been shown (Mesquita et al., 2014; Naude et al., 2012). Indeed, iron homeostasis deregulation may lead to iron accumulation, which is a common feature of such neurodegenerative diseases (Crichton et al., 2011). In fact, the presence of LCN2 in the brain regions associated with $\mathrm{AD}$ pathology in human post-mortem brain tissue (Naude et al., 2012) and in the mediation of $A \beta$ cytotoxicity (Mesquita et al., 2014) may relate to the modulation of iron homeostasis. The function of LCN2 as an iron-chelator in the brain has also been suggested after intracerebral haemorrhage, as part of the response to clear iron released from the haematoma during clot resolution (Dong et al., 2013).

\subsection{In neuroinflammation: neuroprotective or neurodetrimental?}

Inflammation in the CNS (termed neuroinflammation) is common to all neurodegenerative conditions and whenever an injury is imposed in the CNS. The cellular expression of LCN2 under such conditions is known to occur so it can engage critical roles in inflammatory progression. For instance, the secretion of LCN2 by activated astrocytes mediates neuronal toxicity, which can have implications in disease progression (Bi et al., 2013).

Upon stimulation, LCN2 is secreted by astrocytes to act as an autocrine mediator and to stimulate surrounding astrocytes and microglia to become reactive, thus amplifying the inflammatory response (Lee et al., 2007; Lee et al., 2009) and impacting on neurons. Whether this modulation by LCN2 can be considered deleterious or protective is largely controversial presently. Several reports point to LCN2 as a deleterious modulator since, for instance, in the injured brain after ischaemia, LCN2 was shown to contribute to neuronal cell death by potentiating, among others, ischaemic-induced glial activation, neutrophil infiltration and proinflammatory cytokine/chemokine levels (Jin et al., 2014b). Similarly, Lcn2-expression ablation attenuates LPS-induced glial activation in the brain (Jin et al., 2014a) and promotes better locomotor recovery after spinal cord injury (Rathore et al., 2011), reinforcing the view that, when present, LCN2 might contribute to the uncontrolled neurotoxic glial activation under conditions of excessive and chronic inflammation. These results are in accordance with the findings that LCN2 secreted by glial cells in inflammatory conditions up-regulates the expression of $\mathrm{C}-\mathrm{X}-\mathrm{C}$ motif chemokine-10 (Lee et al., 2011), participating in the recruitment of leukocytes to the CNS. This role as an immune cell attractant, through the modulation of chemokines, has implications, for instance, in central sensitization at the site of inflammation and in nociceptive behaviour in chronic inflammatory pain (Jha et al., 2014). Mechanical allodynia (Jha et al., 2014), nociceptive behaviour (Jha et al., 2013) and pain sensitivity (Jeon et al., 2013) are all features of pain processing that were decreased or attenuated in LCN2-null mice (Table 3). However, the observation that LCN2-null mice present a similar inflammatory response to LPS, as controls, suggests a non-essential modulation of gliosis in response to LPS in vivo (Ip et al., 2011).

Opposing to these neurodetrimental effects under inflammation, LCN2 has also been attributed a neuroprotective role. At least in one report concerning MS, LCN2-null mice presented an increased severity of disease manifestation and progression (Berard et al., 2012), accompanied by an increased pro-inflammatory response. It is, therefore, plausible to assume that LCN2 mediates differential effects depending on the type of CNS inflammatory response.

\subsubsection{Lipocalin-2 in multiple sclerosis}

The presence and relevance of LCN2 in different brain diseases is well accepted, but its precise role in disease onset and progression is still debateable. In the particular case of MS, the 
presence of LCN2 and its increased expression has been reported by many (Berard et al., 2012; Marques et al., 2012; Nam et al., 2014), but while some studies point to its neurodeleterious effects (Nam et al., 2014), others suggest that it may be neuroprotective (Berard et al., 2012). Berard and colleagues (2012) demonstrated that the induction of EAE in LCN2-null mice leads to increased disease severity and pro-inflammatory responses, indicating that LCN2 is protective (Berard et al., 2012). Specifically, such increased disease severity was associated with increased lesion burden and IFN- $\gamma$ and TNF expression, both pro-inflammatory cytokines with well-known implication in EAE pathogenesis (Berard et al., 2012). The absence of alterations in IL-4 mRNA levels in LCN2-null mice suggests that the protective function of LCN2 in EAE involves the control of the $T_{h} 1$ immune response, rather than the promotion of an $\mathrm{T}_{\mathrm{h}} 2$ immune response (Berard et al., 2012). The described protective effects are considered to occur towards macrophages/ microglia and reactive astrocytes, but not neurons, as those are the cell populations shown to express 24p3R during the course of the disease (Berard et al., 2012; Nam et al., 2014). On the other hand, Nam and colleagues (2014) showed that LCN2-null mice present a less severe disease phenotype, demonstrated by the lower mean of EAE scores and demyelination, reduced inflammatory infiltration, glial activation and inflammatory cytokine/chemokine expression, when compared to wild-type animals (Nam et al., 2014). Of interest, these authors also showed that upon the adoptive transfer of $\mathrm{T}$ cells from EAE-induced wild-type mice to a LCN2-null mice, the animals developed a normal EAE disease profile, while the transfer of T cells from EAE-induced LCN2-null mice to wild-type mice reduced disease severity, reinforcing the view that LCN2 is detrimental in EAE (Nam et al., 2014). In accordance with this deleterious effect is the observation that increased levels of LCN2 in the CSF coincide with the active phases of the disease and are reverted by natalizumab treatment (an antibody that blocks leucocyte entry into the CNS, currently used as therapeutics) (Marques et al., 2012). The specific engagement of LCN2 in the MS context can, indeed, be related to its previously described involvement in the amplification of M1-polarized phenotypes of microglia, over M2, which is curiously associated with the initiation and perpetuation of inflammation rather than with its resolution (Jang et al., 2013b) (Fig. 2). In addition, astrocytederived LCN2 promotes classical activation of astrocytes (Jang et al., 2013a), which also supports that rather than being involved in the resolution of the inflammatory response, LCN2 contributes to the initiation and installation of the disease. Of interest, LCN2 was also shown to have detrimental effects in a spinal cord injury model (Rathore et al., 2011). Particularly, LCN2-null mice showed better locomotor recovery after spinal cord contusion injury than wild-type mice, and this was accompanied by decreased neutrophil and monocyte influx to the injured spinal cords, as well as by a reduction in the expression of several pro-inflammatory chemokines, cytokines and inducible nitric oxide synthase (Rathore et al., 2011).

The attempt of the described studies to disclose if LCN2 is either protective or deleterious relies on the use of the LCN2-null mouse model, which as a full knockout system has its limitations. Additional studies are, therefore, necessary to further understand whether LCN2 acts in a context-depend manner, and which are the up- and/or down-stream mediators of such responses.

\subsubsection{Lipocalin-2 in Alzheimer's disease}

The engagement of LCN2 in the initiation of an inflammatory response is suggested to promote secondary tissue damage. Indeed, in in vitro studies LCN2 was shown to modulate cell death after inflammatory stimulation of cultured astrocytes: LCN2 increased expression and secretion induced cell death sensitization, stimulation of cell migration and morphological changes of reactive astrocytes (Lee et al., 2009). These observations point to LCN2 as an autocrine mediator of reactive astrocytosis (Lee et al., 2009). Of relevance, this LCN2-induced cytotoxic sensitization was demonstrated to involve iron metabolism and the pro-apoptotic BIM protein, not only in astrocytes but also in activated microglia and neurons (Lee et al., 2007; Lee et al., 2012). Furthermore, it was proposed that degenerating neurons activate quiescent astrocytes and these, in turn, secrete LCN2 to induce neuronal migration, morphological changes and neuronal cell death (Bi et al., 2013; Lee et al., 2012). The mediation of neuronal toxicity by LCN2 is of particular relevance for disease progression. For instance, the strong up-regulation of LCN2 in cortical brain regions of an AD mouse model which overexpresses mutated, but not wild-type forms, of the human amyloid precursor protein and presenilin-1, is suggestive of LCN2 involvement in the establishment of the initial inflammatory response and sensitization of nerve cells to $A \beta$ toxicity (Wu et al., 2006). More recently, the stimulation of neuronal and glial (astrocytes and microglia) cultures with TNF was shown to lead to an increase in LCN2 levels (Naude et al., 2012). In addition, in RNA samples extracted from cortical neurons of mice lacking TNF type 1 receptor (TNFR1) or type 2 (TNFR2) and treated with TNF, LCN2 was specifically induced by the activation of TNFR1 (Naude et al., 2012). Remarkably, binding to this receptor generally leads to pro-inflammatory and pro-apoptotic responses, whereas binding to TNFR2 has been seen associated with neuroprotection. These observations are relevant in the context of $\mathrm{AD}$, since it is known that TNF, through a TNFR2 signalling pathway, can be protective against $A \beta$-induced neuronal cell death (Patel and Brewer, 2008). However, when present, LCN2 can silence neuroprotection against the $\mathrm{AD}$-associated excitotoxic factors via TNFR1-specific signalling (Naude et al., 2012). Of interest, in this same study, LCN2 levels were found to be decreased in CSF of patients with mild cognitive impairment and $A D$, but increased in brain regions associated with AD pathology in human post-mortem brain tissue, with no changes in the serum levels (Naude et al., 2012). However, other authors described, in a distinct cohort of patients, significantly higher LCN2 serum levels in mild cognitive impaired patients, when compared to healthy controls and AD patients (Choi et al., 2011).

In addition to these findings, LCN2 was recently showed to modulate the cellular response to $A \beta$ (Mesquita et al., 2014). In this work, LCN2 production was up-regulated in both CP epithelial cells and astrocytes, but not in microglia or neurons, in response to $A \beta$ (Mesquita et al., 2014). Moreover, LCN2 was shown to be required for $A \beta$ toxicity to astrocytes, as the survival of wild-type astrocytes was decreased upon $A \beta$ stimulation, while astrocytes from LCN2null mice were not affected (Mesquita et al., 2014). This protection was found to result from both a lower expression of the proapoptotic gene Bim and a decreased pro-inflammatory response (Mesquita et al., 2014), which is in accordance with a role for LCN2 in promoting pro-inflammatory response and degeneration.

In all of the described cases, LCN2 production by reactive astrocytes seems a critical step for the course of the disease, whether by potentiating or attenuating the inflammatory response. Further understanding on whether LCN2 is a marker of activated astrocytes by itself, or represents a key mediator in the involvement of astrocytes on CNS pathogenesis, might have important implications for the development of neuroprotective therapeutic strategies.

\section{The promising diagnostic and prognostic value of lipocalin-2}

In the recent years, the increased number of reports demonstrating the nature of secreted LCN2, in several diseases conditions, has suggested its potential value as a biomarker in clinical monitoring. In fact, it is becoming increasingly clear the 
pathophysiologic role of LCN2 in diverse diseases, as described in the present review. In line with this, LCN2 has been proposed as a biomarker for various conditions and has also emerged as an attractive molecular tool with distinct clinical applications. Indeed, its small size, associated with the existence of commercially available immunoassays that quantify LCN2 levels, reinforces such emerging view. However, and although showing high sensitivity, the available immunoassays have low specificity, which is something that has to be improved in the future (Haase et al., 2009).

In the particular case of the kidney, the sustained expression of LCN2 in response to either acute or chronic kidney damage, has gained considerable importance and has led several authors to propose LCN2 as a serum and urinary biomarker for functional, toxic and ischaemic renal damage (An et al., 2013). In fact, several interesting findings have emerged from pre-clinical and clinical studies. For instance, urinary LCN2 levels have become a standard biomarker for both the early diagnosis and the prediction of prognosis of patients with renal injury (Schmidt-Ott et al., 2007). In acute kidney injury, a significant increase in the expression of LCN2 in the kidney is observed (Hirsch et al., 2007). Aligned with a poor sensitivity of creatinine in the early diagnosis of this disease (Kumpers et al., 2010), the positive correlation of LCN2 levels with disease severity (Kumpers et al., 2010) has strengthen the suggestion of LCN2 as an early diagnostic and prognostic marker for these patients. Similarly, in chronic kidney disease, the increased levels of LCN2 in tissue, blood and urine (Viau et al., 2010) correlate with the extent of renal damage. Importantly, in polycystic kidney disease, the levels of LCN2 in patients with rapid disease progression are significantly higher than those with slower progression (Viau et al., 2010). Also, in the cases of patients with stable angina, undergoing percutaneous coronary intervention, the increased level of urinary LCN2 is a strong predictor of mortality (Borkham-Kamphorst et al., 2013).

In addition, several authors are currently pursuing studies on the effectiveness of LCN2 as a marker and predictor of other diseases. The diversity of reports describing LCN2 expression, in animal models of disease and in humans, and under several conditions, strongly suggests for its predictive value. Examples of this are the proposals of LCN2 as a marker of disease progression in post-liver resection (Kienzl-Wagner et al., 2014), asphyxiated newborns (Surmiak et al., 2014), breast cancer (Wang and Zeng, 2013), chronic obstructive pulmonary disease (Wang et al., 2014), systemic lupus erythematosus (Li et al., 2014), heart failure (van Deursen et al., 2014) and nephrolithiasis (Zhu et al., 2014). Nevertheless, in most reports, the suggestion for the need of additional and further studies to dissect the precise reliability of LCN2 as a biomarker is noted. Still, the proposed role of LCN2 in such diseases paves the way for possible therapeutic targeting.

Whether detrimental or protective, also in the CNS context, LCN2 has been profoundly associated to alterations in brain homeostasis and in specific regions that are affected in neurodegenerative disorders, including AD and MS. Due to its peculiar mechanisms of induction and involvement in accelerating neuronal cell death, many authors are also proposing the use of LCN2 as a marker for the diagnosis and prognosis of several neurological diseases. The particular description of increased LCN2 plasma and CSF levels in patients with mild cognitive impairment (Choi et al., 2011), of plasma levels in depression (Naude et al., 2013), but also in the CSF of MS patients (Marques et al., 2012), is suggestive of LCN2's involvement in these pathologies. Specifically, the presence of high LCN2 levels in patients with mild cognitive impairment, considered to be a transitional state between normal and mild dementia, was considered not only to reflect overall CNS inflammation, but also an important marker of progression from one form of dementia to the other (Choi et al., 2011). In this sense, as much as it is risky to say, it is plausible to speculate that higher levels of LCN2 could be associated with a higher risk to develop AD (Choi et al., 2011). However, some cautious should be taken into consideration since in the study by Naude et al. (2012), no changes in the plasma levels for LCN2 in AD and in mild cognitive impairment was observed (Naude et al., 2012). In parallel, the increased plasma levels of LCN2 in subjects with a recurrent depression episode, compared to those in the first episode, points for its potential use as a marker of disease (Naude et al., 2013). This finding further suggests that LCN2 may be an indicator for symptoms of depression, which should be further investigated in detail.

Furthermore, the identification of increased LCN2 CSF levels in MS patients, which also occurs in the EAE animal model, suggests for its putative relevance and possible inclusion in the already existent panel of inflammatory MS markers (Marques et al., 2012). The major drawback at this point concerns the period in the course of the disease that the analyses are performed and, currently, it is not known whether LCN2 levels emerge earlier than current diagnostic markers of the disease (Marques et al., 2012). This can be of clinical relevance so to identify patients that would benefit from early treatment.

Irrespective of the great value of LCN2 from the clinical point of view, we believe that a single marker will be insufficient to track disease progression, particularly when its altered expression is common to such myriad of diseases. For instance, the levels of LCN2 overlap between depressed and non-depressed patients, which certainly limits its use as a single diagnostic marker, in this particular case. Ultimately, the best approach will always be the use of LCN2 in combination with other validated biomarkers. This is certainly a great challenge for the near future and for personalized medicine.

\section{Final remarks}

We performed here a comprehensive revision of the multifaceted LCN2, ranging from its known and postulated functions in the periphery to the latest findings of its involvement in diseases of the CNS. Lipocalin-2 has gained great interest in multidisciplinary fields since its discovery. With a denotable broad expression and rapidly induction upon stimulation, particularly in tissues more prone to infection, the relevance of LCN2 in the acute inflammation and innate immune response is nowadays well accepted. Lipocalin-2 is part of an efficient mechanism of sensing microbial metabolism to modulate the proper host immune response, with iron assuming an important role in such regulation. The existence of specific cell surface receptors for LCN2, and of an endogenous mammalian siderophore, strengthens the role of LCN2 in iron trafficking within cells and as a player on iron homeostasis. The impact of such modulation, whether under physiological or pathological conditions, has been demonstrated to be crucial for cellular equilibrium and homeostasis. Indeed, although iron is the best-known ligand for LCN2, which may explain the impact of LCN2 in innate immunity and in cellular processes such as cell proliferation and death, the role of LCN2 in the modulation of proand anti-inflammatory responses still warrants further research. Also unclear is the mechanism through which LCN2 modulates cellular processes such as cell migration. Is it possible that LCN2 can also bind to other ligands? Has the demonstrated LCN2 binding to phosphatidylethanolamine a role in cellular processes such as dendritic arborisation and cell-to-cell connections, known to be affected in LCN2-null mice?

The precise impact of LCN2 in the CNS is far from being completely unravelled and is considered to be multifaceted. The production of LCN2 by reactive astrocytes is likely to play significant roles in neurodegeneration. From a clinical perspective, 
LCN2 could be targeted therapeutically to dampen pro-inflammatory astrocytic activation. Nonetheless, at this point, the absence of a specific antagonist for LCN2, aligned with a less elucidated mediation of astrocytic neurotoxicity by LCN2 through the binding to specific receptors, makes the task of counteracting LCN2 effects in the progression of CNS diseases very challenging. Filling these and other gaps of knowledge is crucial to assert the already described roles for LCN2 and, possibly, to uncover new ones.

\section{Conflict of interests}

The authors have no conflicting financial interests to declare.

\section{Acknowledgements}

Ana Catarina Ferreira and Sandro Da Mesquita are recipients of PhD fellowships by the Fundação para a Ciência e Tecnologia (FCT, Portugal)/FEDER. Fernanda Marques is an assistant researcher IF/ 00231/2013 of the Fundação para a Ciência e Tecnologia (FCT, Portugal). This work was supported by Fundação para a Ciência e Tecnologia (FCT) and COMPETE through the project: EXPL/NEUOSD/2196/2013 (to Marques F). The authors thank Nadine Santos for the helpful comments on the manuscript.

\section{References}

Aigner, F., Maier, H.T., Schwelberger, H.G., Wallnofer, E.A., Amberger, A., Obrist, P., Berger, T., Mak, T.W., Maglione, M., Margreiter, R., Schneeberger, S., Troppmair, J., 2007. Lipocalin-2 regulates the inflammatory response during ischemia and reperfusion of the transplanted heart. Am. J. Transplant. 7, 779-788.

An, S., Zang, X., Yuan, W., Zhuge, Y., Yu, Q., 2013. Neutrophil gelatinase-associated lipocalin (NGAL) may play a protective role against rats ischemia/reperfusion renal injury via inhibiting tubular epithelial cell apoptosis. Ren. Fail. 35, 143149.

Andrews, N.C., 2008. Forging a field: the golden age of iron biology. Blood 112, 219-230.

Ataseven, A., Kesli, R., Kurtipek, G.S., Ozturk, P., 2014. Assessment of lipocalin 2 clusterin, soluble tumor necrosis factor receptor-1, interleukin-6, homocysteine, and uric acid levels in patients with psoriasis. Dis. Markers.

Auguet, T., Quintero, Y., Terra, X., Martinez, S., Lucas, A., Pellitero, S., Aguilar, C., Hernandez, M., del Castillo, D., Richart, C., 2011. Upregulation of lipocalin 2 in adipose tissues of severely obese women: positive relationship with proinflammatory cytokines. Obesity (Silver Spring) 19, 2295-2300.

Bachman, M.A., Miller, V.L., Weiser, J.N., 2009. Mucosal lipocalin 2 has pro-inflammatory and iron-sequestering effects in response to bacterial enterobactin. PLoS Pathog. 5, e1000622.

Bao, G., Clifton, M., Hoette, T.M., Mori, K., Deng, S.X., Qiu, A., Viltard, M., Williams, D., Paragas, N., Leete, T., Kulkarni, R., Li, X., Lee, B., Kalandadze, A., Ratner, A.J., Pizarro, J.C., Schmidt-Ott, K.M., Landry, D.W., Raymond, K.N., Strong, R.K., Barasch, J., 2010. Iron traffics in circulation bound to a siderocalin (Ngal)catechol complex. Nat. Chem. Biol. 6, 602-609.

Berard, J.L., Zarruk, J.G., Arbour, N., Prat, A., Yong, V.W., Jacques, F.H., Akira, S., David, S., 2012. Lipocalin 2 is a novel immune mediator of experimental autoimmune encephalomyelitis pathogenesis and is modulated in multiple sclerosis. Glia 60, 1145-1159.

Berger, T., Togawa, A., Duncan, G.S., Elia, A.J., You-Ten, A., Wakeham, A., Fong, H.E. Cheung, C.C., Mak, T.W., 2006. Lipocalin 2-deficient mice exhibit increased sensitivity to Escherichia coli infection but not to ischemia-reperfusion injury. Proc. Natl. Acad. Sci. U. S. A. 103, 1834-1839.

Bi, F., Huang, C., Tong, J., Qiu, G., Huang, B., Wu, Q., Li, F., Xu, Z., Bowser, R., Xia, X.G., Zhou, H., 2013. Reactive astrocytes secrete lcn2 to promote neuron death. Proc. Natl. Acad. Sci. U. S. A. 110, 4069-4074.

Borkham-Kamphorst, E., van de Leur, E. Zimmermann, H.W. Karlmark, K.R., Tihaa, L., Haas, U., Tacke, F., Berger, T., Mak, T.W., Weiskirchen, R., 2013. Protective effects of lipocalin-2 (LCN2) in acute liver injury suggest a novel function in liver homeostasis. Biochim. Biophys. Acta 1832, 660-673.

Bratt, T., Ohlson, S., Borregaard, N., 1999. Interactions between neutrophil gelatinase-associated lipocalin and natural lipophilic ligands. Biochim. Biophys. Acta 1472, 262-269.

Bu, D.X., Hemdahl, A.L., Gabrielsen, A., Fuxe, J., Zhu, C., Eriksson, P., Yan, Z.Q., 2006 Induction of neutrophil gelatinase-associated lipocalin in vascular injury via activation of nuclear factor-kappaB. Am. J. Pathol. 169, 2245-2253.

Cassat, J.E., Skaar, E.P., 2013. Iron in infection and immunity. Cell Host Microbe 13 509-519.

Catalan, V., Gomez-Ambrosi, J., Rodriguez, A., Ramirez, B., Silva, C., Rotellar, F., Gil, M.J., Cienfuegos, J.A., Salvador, J., Fruhbeck, G., 2009. Increased adipose tissue expression of lipocalin-2 in obesity is related to inflammation and matrix metalloproteinase-2 and metalloproteinase-9 activities in humans. J. Mol. Med. (Berl.) 87, 803-813.

Chakraborty, S., Kaur, S., Guha, S., Batra, S.K., 2012. The multifaceted roles of neutrophil gelatinase associated lipocalin (NGAL) in inflammation and cancer. Biochim. Biophys. Acta 1826, 129-169.

Chan, Y.R., Liu, J.S., Pociask, D.A., Zheng, M., Mietzner, T.A., Berger, T., Mak, T.W., Clifton, M.C., Strong, R.K., Ray, P., Kolls, J.K., 2009. Lipocalin 2 is required for pulmonary host defense against Klebsiella infection. J. Immunol. 182, 4947-4956.

Chia, W.J., Dawe, G.S., Ong, W.Y., 2011. Expression and localization of the ironsiderophore binding protein lipocalin 2 in the normal rat brain and after kainate-induced excitotoxicity. Neurochem. Int. 59, 591-599.

Chiricozzi, A., Nograles, K.E., Johnson-Huang, L.M., Fuentes-Duculan, J., Cardinale, I., Bonifacio, K.M., Gulati, N., Mitsui, H., Guttman-Yassky, E., Suarez-Farinas, M., Krueger, J.G., 2014. IL-17 induces an expanded range of downstream genes in reconstituted human epidermis model. PLOS ONE 9, e90284.

Choi, J., Lee, H.W., Suk, K., 2011. Increased plasma levels of lipocalin 2 in mild cognitive impairment. J. Neurol. Sci. 305, 28-33.

Coban, C., Ishii, K.J., Horii, T., Akira, S., 2007. Manipulation of host innate immune responses by the malaria parasite. Trends Microbiol. 15, 271-278.

Correnti, C., Richardson, V., Sia, A.K., Bandaranayake, A.D., Ruiz, M., Suryo Rahmanto, Y., Kovacevic, Z., Clifton, M.C., Holmes, M.A., Kaiser, B.K., Barasch, J., Raymond, K.N., Richardson, D.R., Strong, R.K., 2012. Siderocalin/Lcn2/NGAL/24p3 does not drive apoptosis through gentisic acid mediated iron withdrawal in hematopoietic cell lines. PLoS ONE 7, e43696.

Cowland, J.B., Borregaard, N., 1997. Molecular characterization and pattern of tissue expression of the gene for neutrophil gelatinase-associated lipocalin from humans. Genomics 45, 17-23.

Cowland, J.B., Sorensen, O.E., Sehested, M., Borregaard, N., 2003. Neutrophil gelatinase-associated lipocalin is up-regulated in human epithelial cells by IL-1 beta, but not by TNF-alpha. J. Immunol. 171, 6630-6639.

Crichton, R.R., Dexter, D.T., Ward, R.J., 2011. Brain iron metabolism and its perturbation in neurological diseases. J. Neural Transm. 118, 301-314.

Devireddy, L.R., Gazin, C., Zhu, X., Green, M.R., 2005. A cell-surface receptor for lipocalin $24 \mathrm{p} 3$ selectively mediates apoptosis and iron uptake. Cell 123, 1293-1305.

Devireddy, L.R., Hart, D.O., Goetz, D.H., Green, M.R., 2010. A mammalian siderophore synthesized by an enzyme with a bacterial homolog involved in enterobactin production. Cell 141, 1006-1017.

Devireddy, L.R., Teodoro, J.G., Richard, F.A., Green, M.R., 2001. Induction of apoptosis by a secreted lipocalin that is transcriptionally regulated by IL-3 deprivation. Science 293, 829-834.

Ding, L., Hanawa, H., Ota, Y., Hasegawa, G., Hao, K., Asami, F., Watanabe, R., Yoshida, T., Toba, K., Yoshida, K., Ogura, M., Kodama, M., Aizawa, Y., 2010. Lipocalin-2/ neutrophil gelatinase-B associated lipocalin is strongly induced in hearts of rats with autoimmune myocarditis and in human myocarditis. Circ. J. 74, 523-530.

Dong, M., Xi, G., Keep, R.F., Hua, Y., 2013. Role of iron in brain lipocalin 2 upregulation after intracerebral hemorrhage in rats. Brain Res. 1505, 86-92.

Elangovan, N., Lee, Y.C., Tzeng, W.F., Chu, S.T., 2004. Delivery of ferric ion to mouse spermatozoa is mediated by lipocalin internalization. Biochem. Biophys. Res. Commun. 319, 1096-1104.

Eller, K., Schroll, A., Banas, M., Kirsch, A.H., Huber, J.M., Nairz, M., Skvortsov, S., Weiss, G., Rosenkranz, A.R., Theurl, I., 2013. Lipocalin-2 expressed in innate immune cells is an endogenous inhibitor of inflammation in murine nephrotoxic serum nephritis. PLoS ONE 8, e67693.

Fernandez, C.A., Yan, L., Louis, G., Yang, J., Kutok, J.L., Moses, M.A., 2005. The matrix metalloproteinase-9/neutrophil gelatinase-associated lipocalin complex plays a role in breast tumor growth and is present in the urine of breast cancer patients. Clin. Cancer Res. 11, 5390-5395.

Ferreira, A.C., Pinto, V., Da Mesquita, S., Novais, A., Sousa, J.C., Correia-Neves, M., Sousa, N., Palha, J.A., Marques, F., 2013. Lipocalin-2 is involved in emotional behaviors and cognitive function. Front. Cell Neurosci. 7, 122

Ferreira, M.C., Whibley, N., Mamo, A.J., Siebenlist, U., Chan, Y.R., Gaffen, S.L., 2014. Interleukin-17-induced protein lipocalin 2 is dispensable for immunity to oral candidiasis. Infect. Immun. 82, 1030-1035.

Flo, T.H., Smith, K.D., Sato, S., Rodriguez, D.J., Holmes, M.A., Strong, R.K., Akira, S., Aderem, A., 2004. Lipocalin 2 mediates an innate immune response to bacterial infection by sequestrating iron. Nature 432, 917-921.

Flower, D.R., 1994. The lipocalin protein family: a role in cell regulation. FEBS Lett. $354,7-11$

Flower, D.R., 1996. The lipocalin protein family: structure and function. Biochem. J. 318 (Pt 1) 1-14.

Flower, D.R., North, A.C., Sansom, C.E., 2000. The lipocalin protein family: structural and sequence overview. Biochim. Biophys. Acta 1482, 9-24.

Friedl, A., Stoesz, S.P., Buckley, P., Gould, M.N., 1999. Neutrophil gelatinase-associated lipocalin in normal and neoplastic human tissues. Cell type-specific pattern of expression. Histochem. J. 31, 433-441.

Ganz, T., 2009. Iron in innate immunity: starve the invaders. Curr. Opin. Immunol. 21, 63-67.

Gao, H., Liang, M., Bergdahl, A., Hamren, A., Lindholm, M.W., Dahlman-Wright, K., Nilsson, B.O., 2006. Estrogen attenuates vascular expression of inflammation associated genes and adhesion of monocytes to endothelial cells. Inflamm. Res. 55, 349-353.

Garay-Rojas, E., Harper, M., Hraba-Renevey, S., Kress, M., 1996. An apparent autocrine mechanism amplifies the dexamethasone- and retinoic acid-induced expression of mouse lipocalin-encoding gene 24p3. Gene 170, 173-180. 
Garrick, M.D., Garrick, L.M., 2009. Cellular iron transport. Biochim. Biophys. Acta 1790, 309-325.

Gkouvatsos, K., Papanikolaou, G., Pantopoulos, K., 2012. Regulation of iron transport and the role of transferrin. Biochim. Biophys. Acta 1820, 188-202.

Goetz, D.H., Holmes, M.A., Borregaard, N., Bluhm, M.E., Raymond, K.N., Strong, R.K., 2002. The neutrophil lipocalin NGAL is a bacteriostatic agent that interferes with siderophore-mediated iron acquisition. Mol. Cell 10, 1033-1043.

Guglani, L., Gopal, R., Rangel-Moreno, J., Junecko, B.F., Lin, Y., Berger, T., Mak, T.W., Alcorn, J.F., Randall, T.D., Reinhart, T.A., Chan, Y.R., Khader, S.A., 2012. Lipocalin 2 regulates inflammation during pulmonary mycobacterial infections. PLoS ONE 7, e50052.

Guo, H., Jin, D., Chen, X., 2014. Lipocalin 2 is a regulator of macrophage polarization and NF-kappaB/STAT3 pathway activation. Mol. Endocrinol. 28, 1616-1628.

Guo, H., Jin, D., Zhang, Y., Wright, W., Bazuine, M., Brockman, D.A., Bernlohr, D.A., Chen, X., 2010. Lipocalin-2 deficiency impairs thermogenesis and potentiates diet-induced insulin resistance in mice. Diabetes 59, 1376-1385.

Gustine, D.L., Zimmerman, E.F., 1973. Developmental changes in microheterogeneity of foetal plasma glycoproteins of mice. Biochem. J. 132, 541-551.

Haase, M., Bellomo, R., Devarajan, P., Schlattmann, P., Haase-Fielitz, A., Group, N.M.A.I., 2009. Accuracy of neutrophil gelatinase-associated lipocalin (NGAL) in diagnosis and prognosis in acute kidney injury: a systematic review and metaanalysis. Am. J. Kidney Dis. 54, 1012-1024.

Hamill, R.L., Woods, J.C., Cook, B.A., 1991. Congenital atransferrinemia. A case report and review of the literature. Am. J. Clin. Pathol. 96, 215-218.

Hamzic, N., Blomqvist, A., Nilsberth, C., 2013. Immune-induced expression of lipocalin-2 in brain endothelial cells: relationship with interleukin-6, cyclooxygenase-2 and the febrile response. J. Neuroendocrinol. 25, 271-280.

Hashikata, A., Yamashita, A., Suzuki, S., Nagayasu, S., Shinjo, T., Taniguchi, A., Fukushima, M., Nakai, Y., Nin, K., Watanabe, N., Asano, T., Abiko, Y., Kushiyama, A., Nagasaka, S., Nishimura, F., 2014. The inflammation-lipocalin 2 axis may contribute to the development of chronic kidney disease. Nephrol. Dial. Transplant. 29, 611-618.

Hayashi, A., Wada, Y., Suzuki, T., Shimizu, A., 1993. Studies on familial hypotransferrinemia: unique clinical course and molecular pathology. Am. J. Hum. Genet. 53, 201-213.

Henderson, J.P., Crowley, J.R., Pinkner, J.S., Walker, J.N., Tsukayama, P., Stamm, W.E., Hooton, T.M., Hultgren, S.J., 2009. Quantitative metabolomics reveals an epigenetic blueprint for iron acquisition in uropathogenic Escherichia coli. PLoS Pathog. 5, e1000305.

Hirsch, R., Dent, C., Pfriem, H., Allen, J., Beekman 3rd, R.H., Ma, Q., Dastrala, S. Bennett, M., Mitsnefes, M., Devarajan, P., 2007. NGAL is an early predictive biomarker of contrast-induced nephropathy in children. Pediatr. Nephrol. 22, 2089-2095.

Holmes, M.A., Paulsene, W., Jide, X., Ratledge, C., Strong, R.K., 2005. Siderocalin (Lcn 2) also binds carboxymycobactins, potentially defending against mycobacterial infections through iron sequestration. Structure 13, 29-41.

Hraba-Renevey, S., Turler, H., Kress, M., Salomon, C., Weil, R., 1989. SV40-induced expression of mouse gene $24 \mathrm{p} 3$ involves a post-transcriptional mechanism. Oncogene 4, 601-608.

Huang, H.L., Chu, S.T., Chen, Y.H., 1999. Ovarian steroids regulate 24 p3 expression in mouse uterus during the natural estrous cycle and the preimplantation period. J. Endocrinol. 162, 11-19.

Hvidberg, V., Jacobsen, C., Strong, R.K., Cowland, J.B., Moestrup, S.K., Borregaard, N., 2005. The endocytic receptor megalin binds the iron transporting neutrophilgelatinase-associated lipocalin with high affinity and mediates its cellular uptake. FEBS Lett. 579, 773-777.

Iannetti, A., Pacifico, F., Acquaviva, R., Lavorgna, A., Crescenzi, E., Vascotto, C., Tell, G., Salzano, A.M., Scaloni, A., Vuttariello, E., Chiappetta, G., Formisano, S., Leonardi, A., 2008. The neutrophil gelatinase-associated lipocalin (NGAL), a NF-kappaBregulated gene, is a survival factor for thyroid neoplastic cells. Proc. Natl. Acad. Sci. U. S. A. $105,14058-14063$.

Ip, J.P., Nocon, A.L., Hofer, M.J., Lim, S.L., Muller, M., Campbell, I.L., 2011. Lipocalin 2 in the central nervous system host response to systemic lipopolysaccharide administration. J. Neuroinflamm. 8, 124

Iqbal, N., Choudhary, R., Chan, J., Wentworth, B., Higginbotham, E., Maisel, A.S., 2013. Neutrophil gelatinase-associated lipocalin as diagnostic and prognostic tool for cardiovascular disease and heart failure. Expert Opin. Med. Diagn. 7, 209-220.

Jang, E., Kim, J.H., Lee, S., Kim, J.H., Seo, J.W., Jin, M., Lee, M.G., Jang, I.S., Lee, W.H., Suk, K., 2013a. Phenotypic polarization of activated astrocytes: the critical role of lipocalin-2 in the classical inflammatory activation of astrocytes. J. Immunol. 191, 5204-5219.

Jang, E., Lee, S., Kim, J.H., Kim, J.H., Seo, J.W., Lee, W.H., Mori, K., Nakao, K., Suk, K., 2013b. Secreted protein lipocalin-2 promotes microglial M1 polarization. FASEB J. 27, 1176-1190.

Jang, Y., Lee, J.H., Wang, Y., Sweeney, G., 2012. Emerging clinical and experimental evidence for the role of lipocalin-2 in metabolic syndrome. Clin. Exp. Pharmacol. Physiol. 39, 194-199.

Jeon, S., Jha, M.K., Ock, J., Seo, J., Jin, M., Cho, H., Lee, W.H., Suk, K., 2013. Role of lipocalin-2-chemokine axis in the development of neuropathic pain following peripheral nerve injury. J. Biol. Chem. 288, 24116-24127.

Jha, M.K., Jeon, S., Jin, M., Lee, W.H., Suk, K., 2013. Acute phase protein lipocalin-2 is associated with formalin-induced nociception and pathological pain. Immune Netw. 13, 289-294.

Jha, M.K., Jeon, S., Jin, M., Ock, J., Kim, J.H., Lee, W.H., Suk, K., 2014. The pivotal role played by lipocalin-2 in chronic inflammatory pain. Exp. Neurol. 254 41-53.
Jiang, W., Constante, M., Santos, M.M., 2008. Anemia upregulates lipocalin 2 in the liver and serum. Blood Cells. Mol. Dis. 41, 169-174.

Jin, M., Jang, E., Suk, K., 2014a. Lipocalin-2 acts as a neuroinflammatogen in lipopolysaccharide-injected mice. Exp. Neurobiol. 23, 155-162.

Jin, M., Kim, J.H., Jang, E., Lee, Y.M., Soo Han, H., Woo, D.K., Park, D.H., Kook, H., Suk, K., 2014b. Lipocalin-2 deficiency attenuates neuroinflammation and brain injury after transient middle cerebral artery occlusion in mice. J. Cereb. Blood Flow Metab.

Kamata, M., Tada, Y., Tatsuta, A., Kawashima, T., Shibata, S., Mitsui, H., Asano, Y., Sugaya, M., Kadono, T., Kanda, N., Watanabe, S., Sato, S., 2012. Serum lipocalin-2 levels are increased in patients with psoriasis. Clin. Exp. Dermatol. 37 296-299.

Kienzl-Wagner, K., Moschen, A.R., Geiger, S., Bichler, A., Aigner, F., Brandacher, G., Pratschke, J., Tilg, H., 2014. The role of lipocalin-2 in liver regeneration. Liver Int.

Kjeldsen, L., Bainton, D.F., Sengelov, H., Borregaard, N., 1994. Identification of neutrophil gelatinase-associated lipocalin as a novel matrix protein of specific granules in human neutrophils. Blood 83, 799-807.

Kjeldsen, L., Cowland, J.B., Borregaard, N., 2000. Human neutrophil gelatinaseassociated lipocalin and homologous proteins in rat and mouse. Biochim. Biophys. Acta 1482, 272-283.

Kjeldsen, L., Johnsen, A.H., Sengelov, H., Borregaard, N., 1993. Isolation and primary structure of NGAL, a novel protein associated with human neutrophil gelatinase. J. Biol. Chem. 268, 10425-10432.

Kumpers, P., Hafer, C., Lukasz, A., Lichtinghagen, R., Brand, K., Fliser, D., FaulhaberWalter, R., Kielstein, J.T., 2010. Serum neutrophil gelatinase-associated lipocalin at inception of renal replacement therapy predicts survival in critically ill patients with acute kidney injury. Crit. Care 14, R9.

La Manna, G., Ghinatti, G., Tazzari, P.L., Alviano, F., Ricci, F., Capelli, I., Cuna, V. Todeschini, P., Brunocilla, E., Pagliaro, P., Bonsi, L., Stefoni, S., 2014. Neutrophil gelatinase-associated lipocalin increases HLA-G(+)/FoxP3(+) T-regulatory cell population in an in vitro model of PBMC. PLOS ONE 9, e89497.

Labbus, K., Henning, M., Borkham-Kamphorst, E., Geisler, C., Berger, T., Mak, T.W., Knuchel, R., Meyer, H.E., Weiskirchen, R., Henkel, C., 2013. Proteomic profiling in Lipocalin 2 deficient mice under normal and inflammatory conditions. J. Proteomics $78,188-196$

Landro, L., Damas, J.K., Flo, T.H., Heggelund, L., Ueland, T., Tjonnfjord, G.E., Espevik, T., Aukrust, P., Froland, S.S., 2008. Decreased serum lipocalin-2 levels in human immunodeficiency virus-infected patients: increase during highly active antiretroviral therapy. Clin. Exp. Immunol. 152, 57-63.

Law, I.K., Xu, A., Lam, K.S., Berger, T., Mak, T.W., Vanhoutte, P.M., Liu, J.T., Sweeney, G., Zhou, M., Yang, B., Wang, Y., 2010. Lipocalin-2 deficiency attenuates insulin resistance associated with aging and obesity. Diabetes 59, 872-882.

Le, P.T., Pearce, M.M., Zhang, S., Campbell, E.M., Fok, C.S., Mueller, E.R., Brincat, C.A., Wolfe, A.J., Brubaker, L., 2014. IL22 regulates human urothelial cell sensory and innate functions through modulation of the acetylcholine response, immunoregulatory cytokines and antimicrobial peptides: assessment of an in vitro model. PLOS ONE 9, e111375.

Lee, H.J., Lee, E.K., Lee, K.J., Hong, S.W., Yoon, Y., Kim, J.S., 2006. Ectopic expression of neutrophil gelatinase-associated lipocalin suppresses the invasion and liver metastasis of colon cancer cells. Int. J. Cancer 118, 2490-2497.

Lee, S., Kim, J.H., Kim, J.H., Seo, J.W., Han, H.S., Lee, W.H., Mori, K., Nakao, K., Barasch, J., Suk, K., 2011. Lipocalin-2 Is a chemokine inducer in the central nervous system: role of chemokine ligand 10 (CXCL10) in lipocalin-2-induced cell migration. J. Biol. Chem. 286, 43855-43870.

Lee, S., Lee, J., Kim, S., Park, J.Y., Lee, W.H., Mori, K., Kim, S.H., Kim, I.K., Suk, K., 2007. A dual role of lipocalin 2 in the apoptosis and deramification of activated microglia. J. Immunol. 179, 3231-3241.

Lee, S., Lee, W.H., Lee, M.S., Mori, K., Suk, K., 2012. Regulation by lipocalin-2 of neuronal cell death, migration, and morphology. J. Neurosci. Res. 90, 540-550.

Lee, S., Park, J.Y., Lee, W.H., Kim, H., Park, H.C., Mori, K., Suk, K., 2009. Lipocalin-2 is an autocrine mediator of reactive astrocytosis. J. Neurosci. 29, 234-249.

Levy, J.E., Jin, O., Fujiwara, Y., Kuo, F., Andrews, N.C., 1999. Transferrin receptor is necessary for development of erythrocytes and the nervous system. Nat. Genet 21, 396-399.

Li, C., Chan, Y.R., 2011. Lipocalin 2 regulation and its complex role in inflammation and cancer. Cytokine 56, 435-441.

Li, Y., Hu, F., Dai, Y., Li, R., Ma, X., Du, Y., Feng, M., Jia, Y., Zhang, C., Zhu, L., Ascherman, D., Li, Z., 2014. Serum anti-lipocalin 2 IgG is a novel biomarker in the diagnosis of systemic lupus erythematosus. Lupus 23, 868-875.

Lin, H., Monaco, G., Sun, T., Ling, X., Stephens, C., Xie, S., Belmont, J., Arlinghaus, R. 2005. Bcr-Abl-mediated suppression of normal hematopoiesis in leukemia. Oncogene 24, 3246-3256.

Liu, Q., Nilsen-Hamilton, M., 1995. Identification of a new acute phase protein. J Biol. Chem. 270, 22565-22570.

Liu, Z., Reba, S., Chen, W.D., Porwal, S.K., Boom, W.H., Petersen, R.B., Rojas, R., Viswanathan, R., Devireddy, L., 2014. Regulation of mammalian siderophore 2,5-DHBA in the innate immune response to infection. J. Exp. Med. 211, 1197 1213

Liu, Z., Yang, A., Wang, Z., Bunting, K.D., Davuluri, G., Green, M.R., Devireddy, L.R., 2011. Multiple apoptotic defects in hematopoietic cells from mice lacking lipocalin 24p3. J. Biol. Chem. 286, 20606-20614.

Mallbris, L., O'Brien, K.P., Hulthen, A., Sandstedt, B., Cowland, J.B., Borregaard, N., Stahle-Backdahl, M., 2002. Neutrophil gelatinase-associated lipocalin is a marker for dysregulated keratinocyte differentiation in human skin. Exp. Dermatol. 11, 584-591. 
Marques, F., Falcao, A.M., Sousa, J.C., Coppola, G., Geschwind, D., Sousa, N., CorreiaNeves, M., Palha, J.A., 2009. Altered iron metabolism is part of the choroid plexus response to peripheral inflammation. Endocrinology 150, 2822-2828.

Marques, F., Mesquita, S.D., Sousa, J.C., Coppola, G., Gao, F., Geschwind, D.H. Columba-Cabezas, S., Aloisi, F., Degn, M., Cerqueira, J.J., Sousa, N., Correia-Neves, M., Palha, J.A., 2012. Lipocalin 2 is present in the EAE brain and is modulated by natalizumab. Front. Cell Neurosci. 6, 33.

Marques, F., Rodrigues, A.J., Sousa, J.C., Coppola, G., Geschwind, D.H., Sousa, N., Correia-Neves, M., Palha, J.A., 2008. Lipocalin 2 is a choroid plexus acute-phase protein. J. Cereb. Blood Flow Metab. 28, 450-455

Marques, F., Sousa, J.C., 2015. The choroid plexus is modulated by various periphera stimuli: implications to diseases of the central nervous system. Front. Cell Neurosci. 9

Matsuo, S., Yamazaki, S., Takeshige, K., Muta, T., 2007. Crucial roles of binding sites for NF-kappaB and C/EBPs in IkappaB-zeta-mediated transcriptional activation. Biochem. J. 405, 605-615.

Meheus, L.A., Fransen, L.M., Raymackers, J.G., Blockx, H.A., Van Beeumen, J.J., Van Bun, S.M., Van de Voorde, A., 1993. Identification by microsequencing of lipopolysaccharide-induced proteins secreted by mouse macrophages. J. Immunol. 151, 1535-1547.

Mesquita, S.D., Ferreira, A.C., Falcao, A.M., Sousa, J.C., Oliveira, T.G., Correia-Neves M., Sousa, N., Marques, F., Palha, J.A., 2014. Lipocalin 2 modulates the cellular response to amyloid beta. Cell Death Differ.

Miao, Q., Ku, A.T., Nishino, Y., Howard, J.M., Rao, A.S., Shaver, T.M., Garcia, G.E., Le, D.N. Karlin, K.L., Westbrook, T.F., Poli, V., Nguyen, H., 2014. Tcf3 promotes cell migration and wound repair through regulation of lipocalin 2. Nat. Commun. 5,4088 .

Miethke, M., Marahiel, M.A., 2007. Siderophore-based iron acquisition and pathogen control. Microbiol. Mol. Biol. Rev. 71, 413-451.

Miharada, K., Hiroyama, T., Sudo, K., Nagasawa, T., Nakamura, Y., 2005. Lipocalin 2 functions as a negative regulator of red blood cell production in an autocrine fashion. FASEB J. 19, 1881-1883.

Mucha, M., Skrzypiec, A.E., Schiavon, E., Attwood, B.K., Kucerova, E., Pawlak, R., 2011 Lipocalin-2 controls neuronal excitability and anxiety by regulating dendritic spine formation and maturation. Proc. Natl. Acad. Sci. U. S. A. 108, 18436-18441.

Nairz, M., Theurl, I., Schroll, A., Theurl, M., Fritsche, G., Lindner, E., Seifert, M., Crouch, M.L., Hantke, K., Akira, S., Fang, F.C., Weiss, G., 2009. Absence of functional Hfe protects mice from invasive Salmonella enterica serovar Typhimurium infection via induction of lipocalin-2. Blood 114, 3642-3651

Nam, Y., Kim, J.H., Seo, M., Kim, J.H., Jin, M., Jeon, S., Seo, J.W., Lee, W.H., Bing, S.J., Jee, Y Lee, W.K., Park, D.H., Kook, H., Suk, K., 2014. Lipocalin-2 deficiency ameliorates experimental autoimmune encephalomyelitis: the pathogenic role of lipocalin-2 in the central nervous system and peripheral lymphoid tissues. J. Biol. Chem..

Naude, P.J., Eisel, U.L., Comijs, H.C., Groenewold, N.A., De Deyn, P.P., Bosker, F.J., Luiten, P.G., den Boer, J.A., Oude Voshaar, R.C., 2013. Neutrophil gelatinaseassociated lipocalin: a novel inflammatory marker associated with late-life depression. J. Psychosom. Res. 75, 444-450.

Naude, P.J., Nyakas, C., Eiden, L.E., Ait-Ali, D., van der Heide, R., Engelborghs, S. Luiten, P.G., De Deyn, P.P., den Boer, J.A., Eisel, U.L., 2012. Lipocalin 2: nove component of proinflammatory signaling in Alzheimer's disease. FASEB J. 26, 2811-2823.

Nelson, A.L., Barasch, J.M., Bunte, R.M., Weiser, J.N., 2005. Bacterial colonization of nasal mucosa induces expression of siderocalin, an iron-sequestering component of innate immunity. Cell. Microbiol. 7, 1404-1417.

Nocon, A.L., Ip, J.P., Terry, R., Lim, S.L., Getts, D.R., Muller, M., Hofer, M.J., King, N.J., Campbell, I.L., 2014. The bacteriostatic protein lipocalin 2 is induced in the central nervous system of mice with west Nile virus encephalitis. J. Virol. 88 679-689.

Owen, H.C., Roberts, S.J., Ahmed, S.F., Farquharson, C., 2008. Dexamethasoneinduced expression of the glucocorticoid response gene lipocalin 2 in chondrocytes. Am. J. Physiol. Endocrinol. Metab. 294, E1023-E1034.

Patel, J.R., Brewer, G.J., 2008. Age-related differences in NFkappaB translocation and Bcl-2/Bax ratio caused by TNFalpha and Abeta42 promote survival in middleage neurons and death in old neurons. Exp. Neurol. 213, 93-100.

Patsaoura, A., Tatsi, E., Margeli, A., Kanavaki, I., Delaporta, P., Kyriakopoulou, D. Kouraklis-Symeonidis, A., Kattamis, A., Papassotiriou, I., 2014. Plasma neutrophil gelatinase-associated lipocalin levels are markedly increased in patients with non-transfusion-dependent thalassemia: lack of association with markers of erythropoiesis, iron metabolism and renal function. Clin. Biochem. 47, 1060-1064.

Poh, K.W., Yeo, J.F., Stohler, C.S., Ong, W.Y., 2012. Comprehensive gene expression profiling in the prefrontal cortex links immune activation and neutrophil infiltration to antinociception. J. Neurosci. 32, 35-45.

Raffatellu, M., George, M.D., Akiyama, Y., Hornsby, M.J., Nuccio, S.P., Paixao, T.A. Butler, B.P., Chu, H., Santos, R.L., Berger, T., Mak, T.W., Tsolis, R.M., Bevins, C.L., Solnick, J.V., Dandekar, S., Baumler, A.J., 2009. Lipocalin-2 resistance confers an advantage to Salmonella enterica serotype Typhimurium for growth and survival in the inflamed intestine. Cell Host Microbe 5, 476-486.

Rathore, K.I., Berard, J.L., Redensek, A., Chierzi, S., Lopez-Vales, R., Santos, M., Akira, S., David, S., 2011. Lipocalin 2 plays an immunomodulatory role and has detrimental effects after spinal cord injury. J. Neurosci. 31, 13412-13419.

Richardson, D.R., 2005. 24p3 and its receptor: dawn of a new iron age? Cell 123 1175-1177.

Rodvold, J.J., Mahadevan, N.R., Zanetti, M., 2012. Lipocalin 2 in cancer: when good immunity goes bad. Cancer Lett. 316, 132-138.
Saiga, H., Nishimura, J., Kuwata, H., Okuyama, M., Matsumoto, S., Sato, S., Matsumoto, M. Akira, S., Yoshikai, Y., Honda, K., Yamamoto, M., Takeda, K., 2008. Lipocalin 2-dependent inhibition of mycobacterial growth in alveolar epithelium. J. Immunol. 181, 8521-8527.

Schaible, U.E., Kaufmann, S.H., 2004. Iron and microbial infection. Nat. Rev. Microbiol. 2, 946-953.

Schmidt-Ott, K.M., Mori, K., Li, J.Y., Kalandadze, A., Cohen, D.J., Devarajan, P., Barasch, J., 2007. Dual action of neutrophil gelatinase-associated lipocalin. J. Am. Soc. Nephrol. 18, 407-413.

Schroll, A., Eller, K., Feistritzer, C., Nairz, M., Sonnweber, T., Moser, P.A., Rosenkranz, A.R., Theurl, I., Weiss, G., 2012. Lipocalin-2 ameliorates granulocyte functionality. Eur. J. Immunol. 42, 3346-3357.

Seth, P., Porter, D., Lahti-Domenici, J., Geng, Y., Richardson, A., Polyak, K., 2002. Cellular and molecular targets of estrogen in normal human breast tissue. Cancer Res. 62, 4540-4544.

Shashidharamurthy, R., Machiah, D., Aitken, J.D., Putty, K., Srinivasan, G., Chassaing B., Parkos, C.A., Selvaraj, P., Vijay-Kumar, M., 2013. Differential role of lipocalin 2 during immune complex-mediated acute and chronic inflammation in mice. Arthritis Rheum. 65, 1064-1073.

Shen, F., Hu, Z., Goswami, J., Gaffen, S.L., 2006. Identification of common transcriptional regulatory elements in interleukin-17 target genes. J. Biol. Chem. 281, 24138-24148

Shen, F., Ruddy, M.J., Plamondon, P., Gaffen, S.L., 2005. Cytokines link osteoblasts and inflammation: microarray analysis of interleukin-17- and TNF-alpha-induced genes in bone cells. J. Leukoc. Biol. 77, 388-399.

Skrzypiec, A.E., Shah, R.S., Schiavon, E., Baker, E., Skene, N., Pawlak, R., Mucha, M., 2013. Stress-induced lipocalin-2 controls dendritic spine formation and neuronal activity in the amygdala. PLoS ONE 8, e61046.

Sorensen, O.E., Cowland, J.B., Theilgaard-Monch, K., Liu, L., Ganz, T., Borregaard, N., 2003. Wound healing and expression of antimicrobial peptides/polypeptides in human keratinocytes, a consequence of common growth factors. J. Immunol. $170,5583-5589$

Spiropoulos, A., Goussetis, E., Margeli, A., Premetis, E., Skenderi, K., Graphakos, S., Baltopoulos, P., Tsironi, M., Papassotiriou, I., 2010. Effect of inflammation induced by prolonged exercise on circulating erythroid progenitors and markers of erythropoiesis. Clin. Chem. Lab. Med. 48, 199-203.

Stuckey, R., Aldridge, T., Lim, F.L., Moore, D.J., Tinwell, H., Doherty, N., Davies, R., Smith, A.G., Kimber, I., Ashby, J., Orphanides, G., Moggs, J.G., 2006. Induction of iron homeostasis genes during estrogen-induced uterine growth and differentiation. Mol. Cell. Endocrinol. 253, 22-29.

Sun, Y., Yokoi, K., Li, H., Gao, J., Hu, L., Liu, B., Chen, K., Hamilton, S.R., Fan, D., Sun, B., Zhang, W., 2011. NGAL expression is elevated in both colorectal adenomacarcinoma sequence and cancer progression and enhances tumorigenesis in xenograft mouse models. Clin. Cancer Res. 17, 4331-4340.

Sunil, V.R., Patel, K.J., Nilsen-Hamilton, M., Heck, D.E., Laskin, J.D., Laskin, D.L., 2007. Acute endotoxemia is associated with upregulation of lipocalin $24 \mathrm{p} 3 / \mathrm{Lcn} 2$ in lung and liver. Exp. Mol. Pathol. 83, 177-187.

Surmiak, P., Baumert, M., Fiala, M., Sypniewska, K., Walencka, Z., Lukomska, A. Karcz, K., 2014. Umbilical cord blood NGAL concentration as an early marker of perinatal asphyxia in neonates. Ginekol. Pol. 85, 424-427.

Tan, B.K., Adya, R., Shan, X., Syed, F., Lewandowski, K.C., O’Hare, J.P., Randeva, H.S. 2009. Ex vivo and in vivo regulation of lipocalin-2, a novel adipokine, by insulin. Diabetes Care 32, 129-131.

Thouvenot, E., Lafon-Cazal, M., Demettre, E., Jouin, P., Bockaert, J., Marin, P., 2006 The proteomic analysis of mouse choroid plexus secretome reveals a high protein secretion capacity of choroidal epithelial cells. Proteomics 6, 59415952.

Torti, S.V., Torti, F.M., 2013. Iron and cancer: more ore to be mined. Nat. Rev. Cancer $13,342-355$.

Trenor 3rd, C.C., Campagna, D.R., Sellers, V.M., Andrews, N.C., Fleming, M.D., 2000. The molecular defect in hypotransferrinemic mice. Blood 96, 1113-1118.

van Deursen, V.M., Damman, K., Voors, A.A., van der Wal, M.H., Jaarsma, T., van Veldhuisen, D.J., Hillege, H.L., 2014. Prognostic value of plasma neutrophil gelatinase-associated lipocalin for mortality in patients with heart failure. Circ. Heart Fail. 7, 35-42.

Vazquez, D.E., Nino, D.F., De Maio, A., Cauvi, D.M., 2014. Sustained expression of lipocalin-2 during polymicrobial sepsis. Innate Immun..

Viau, A., El Karoui, K., Laouari, D., Burtin, M., Nguyen, C., Mori, K., Pillebout, E., Berger T., Mak, T.W., Knebelmann, B., Friedlander, G., Barasch, J., Terzi, F., 2010. Lipocalin 2 is essential for chronic kidney disease progression in mice and humans. J. Clin. Invest. 120, 4065-4076.

Wang, X.R., Li, Y.P., Gao, S., Xia, W., Gao, K., Kong, Q.H., Qi, H., Wu, L., Zhang, J., Qu, J.M., Bai, C.X., 2014. Increased serum levels of lipocalin-1 and -2 in patients with stable chronic obstructive pulmonary disease. Int. J. Chron. Obstruct. Pulmon. Dis. 9, 543-549.

Wang, Y., Zeng, T., 2013. Neutrophil gelatinase-associated lipocalin protein as a biomarker in the diagnosis of breast cancer: a meta-analysis. Biomed. Rep. 1, 479-483.

Watanabe, H., Takeo, T., Tojo, H., Sakoh, K., Berger, T., Nakagata, N., Mak, T.W., Kondoh, G., 2014. Lipocalin 2 binds to membrane phosphatidylethanolamine to induce lipid raft movement in a PKA-dependent manner and modulates sperm maturation. Development 141, 2157-2164.

Wu, H., Santoni-Rugiu, E., Ralfkiaer, E., Porse, B.T., Moser, C., Hoiby, N., Borregaard, N., Cowland, J.B., 2010. Lipocalin 2 is protective against E. coli pneumonia. Respir. Res. 11, 96. 
Wu, Z.L., Ciallella, J.R., Flood, D.G., O'Kane, T.M., Bozyczko-Coyne, D., Savage, M.J., 2006. Comparative analysis of cortical gene expression in mouse models of Alzheimer's disease. Neurobiol. Aging 27, 377-386.

Xing, C., Wang, X., Cheng, C., Montaner, J., Mandeville, E., Leung, W., van Leyen, K., Lok, J., Wang, X., Lo, E.H., 2014. Neuronal production of lipocalin-2 as a help-me signal for glial activation. Stroke.

Xu, G., Ahn, J., Chang, S., Eguchi, M., Ogier, A., Han, S., Park, Y., Shim, C., Jang, Y., Yang, B., Xu, A., Wang, Y., Sweeney, G., 2012. Lipocalin-2 induces cardiomyocyte apoptosis by increasing intracellular iron accumulation. J. Biol. Chem. 287, 4808-4817.

Yan, Q.W., Yang, Q., Mody, N., Graham, T.E., Hsu, C.H., Xu, Z., Houstis, N.E., Kahn, B.B., Rosen, E.D., 2007. The adipokine lipocalin 2 is regulated by obesity and promotes insulin resistance. Diabetes 56, 2533-2540.

Yang, J., Goetz, D., Li, J.Y., Wang, W., Mori, K., Setlik, D., Du, T., Erdjument-Bromage, H., Tempst, P., Strong, R., Barasch, J., 2002. An iron delivery pathway mediated by a lipocalin. Mol. Cell 10, 1045-1056.

Yang, J., McNeish, B., Butterfield, C., Moses, M.A., 2013. Lipocalin 2 is a novel regulator of angiogenesis in human breast cancer. FASEB J. 27, 45-50.

Yoo, H.J., Hwang, H.J., Jung, T.W., Ryu, J.Y., Hong, H.C., Choi, H.Y., Baik, S.H., Choi, K.M., 2014. Adipose gene expression profiles related to metabolic syndrome using microarray analyses in two different models. Diabetes Metab. J. 38, 356-365.

Zhang, J., Wu, Y., Zhang, Y., Leroith, D., Bernlohr, D.A., Chen, X., 2008. The role of lipocalin 2 in the regulation of inflammation in adipocytes and macrophages. Mol. Endocrinol. 22, 1416-1426.

Zhang, Y., Foncea, R., Deis, J.A., Guo, H., Bernlohr, D.A., Chen, X., 2014. Lipocalin 2 expression and secretion is highly regulated by metabolic stress, cytokines, and nutrients in adipocytes. PLOS ONE 9, e96997.

Zhao, H., Konishi, A., Fujita, Y., Yagi, M., Ohata, K., Aoshi, T., Itagaki, S., Sato, S., Narita H., Abdelgelil, N.H., Inoue, M., Culleton, R., Kaneko, O., Nakagawa, A., Horii, T., Akira, S., Ishii, K.J., Coban, C., 2012. Lipocalin 2 bolsters innate and adaptive immune responses to blood-stage malaria infection by reinforcing host iron metabolism. Cell Host Microbe 12, 705-716.

Zhao, P., Stephens, J.M., 2013. STAT1, NF-kappaB and ERKs play a role in the induction of lipocalin-2 expression in adipocytes. Mol. Metab. 2, 161-170.

Zhu, W., Liu, M., Wang, G.C., Che, J.P., Xu, Y.F., Peng, B., Zheng, J.H., 2014. Urinary neutrophil gelatinase-associated lipocalin, a biomarker for systemic inflammatory response syndrome in patients with nephrolithiasis. J. Surg. Res. 187, 237-243. 